NBER WORKING PAPER SERIES

\title{
THE LONG-TERM CONSEQUENCES OF FREE SCHOOL CHOICE
}

\author{
Victor Lavy \\ Working Paper 20843 \\ http://www.nber.org/papers/w20843 \\ NATIONAL BUREAU OF ECONOMIC RESEARCH \\ 1050 Massachusetts Avenue \\ Cambridge, MA 02138 \\ January 2015
}

Excellent research assistance was provided by Elior Cohen, Michal Hodor and Assaf Kott. I benefitted from comments and suggestions from participants at the Bergen/UCL/Warwick 2015 Topics in Labor Economics Workshop, the CESifo 2015 Conference on Economics of Education, The London Centre for the Study of Market Reform of Education 2016 School Choice Conference, seminars at the Hebrew University, the Ministry of Education in Madrid, Warwick University and from Gordon Dahl, David Deming, Christian Dustman, Magne Mogstad, Steve Machin, Craig Riddell, Kjell Salvanes, Uta Schoenberg, and Fabian Waldinger. I thank Israel's National Insurance Institute (NII) for allowing restricted access to post-secondary schooling and economic and social outcomes data at adulthood in the NII protected research lab. I acknowledge financial support from the European Research Council through ERC Advance Grant 323439, The Israel Science Foundation and the Falk Research Institute. The views expressed herein are those of the author and do not necessarily reflect the views of the National Bureau of Economic Research.

NBER working papers are circulated for discussion and comment purposes. They have not been peerreviewed or been subject to the review by the NBER Board of Directors that accompanies official NBER publications.

(C) 2015 by Victor Lavy. All rights reserved. Short sections of text, not to exceed two paragraphs, may be quoted without explicit permission provided that full credit, including $(\mathrm{C}$ notice, is given to the source. 
The Long-Term Consequences of Free School Choice

Victor Lavy

NBER Working Paper No. 20843

January 2015, Revised February 2017

JEL No. J24

\section{ABSTRACT}

I study the long-term consequences of what amounted to an effective free school choice program which two decades ago targeted disadvantaged students in Israel. I show that the program led to significant gains in post-secondary education, through increased enrollment in academic and teachers' colleges but without any increase in enrollment in research universities. Free school choice increased also earnings at adulthood of treated students. Male students had much larger improvements in college schooling and labor market outcomes. Female students, however, experienced higher increases in marriage and fertility rates, which most likely interfered with their schooling and labor market outcomes.

Victor Lavy

Department of Economics

University of Warwick

Coventry, CV4 7AL

United Kingdom

and Hebrew University of Jerusalem

and also NBER

v.lavy@warwick.ac.uk

A Data Appendix is available at http://www.nber.org/data-appendix/w20843 


\section{Introduction}

The evaluation of educational programs and interventions has focused on short-term outcomes, primarily standardized test scores, as a measure of success. However, understanding that the purpose of education is to improve lifetime well-being, attention has shifted recently to long term consequences at adulthood. In light of the increasing economic returns to higher education, the initial focus has been on post-secondary attainment (Heckman and LaFontaine 2010; Acemoglu and Autor 2010). Garces et al (2002), Ludwig and Miller (2007) and Deming (2009) studied the long-term benefits of Head Start; Schweinhart et al (2005) examined the long term effect of the Perry Preschool program; Chetty et al (2011) studied the effect of kindergarten classroom on earnings in early adulthood; Dustmann et al (2012) examined the effect of high school quality on completed schooling and labor-market outcomes; Dynarski et al (2013) examined the effect of smaller classes in primary school on college entry, college choice, and degree completion; Deming et al (2013) studied the impact of accountability pressure in high schools on post-secondary attainment and earnings; Chetty et al (2014) examined the earnings consequences of primary and middle school teacher quality; and Deming, Billings, and Rockoff (2014) studied the impact of the end of race-based busing on college attainment and young adult crime.

The common goal of these studies is to determine which interventions are more effective in improving long-term outcomes, but the scope of educational interventions studied is still limited, and much remains to be unraveled. In this paper I study the long term consequences of free school choice offered to primary school students at the point of transition to secondary schools. The main question I address here is whether the effects of free school choice persist beyond attainment and test scores in high school, and lead to long-term enhancements to human capital and well-being. I do so using a school choice experiment which was conducted two decades ago in the city of Tel Aviv, Israel. The program had positive short and medium-term effects on cognitive outcomes and schooling attainment during middle and high school and improved students' social skills (Lavy 2010). In this paper I study whether the free school choice among public schools had long-term effects on social and economic outcomes. This paper provides the first evidence of links between school choice, students' employment and earnings, and social outcomes at adulthood. I examine the impact on various types of post-secondary schooling that vary by quality, on employment, and on earnings at 11-13 years after high school graduation, almost two decades after students were able to exercise free school choice.

I observe students' outcomes every year from high school graduation (2000-2001), until age 30-32 (in 2014). Thus, I can estimate the treatment effects for every year in the period, and trace the dynamic evolution of the program effect. Since a high proportion of the sample was in military service for two (female) or three (male) years after high school ${ }^{1}$, the estimates for these years (2000-

\footnotetext{
${ }^{1}$ Israelis begin a period of compulsory military service after high-school graduation. Boys serve for three years and girls for two (longer if they take a commission). Ultra-orthodox Jews are exempt from military service as
} 
2004) are not very informative, because they are based on a small and selective sample of those students not enlisted into military service. The evidence shows that the school choice had increased post secondary schooling. Treated students are 4.6 percentage points more likely to enroll in post secondary schooling, and complete almost an additional a fifth year of college in comparison to students in the control group. These effect sizes reflect an 11 percent increase relative to pre-program means and are similar in magnitude to the effect of the program on end of high school matriculation outcomes. The increase in post-secondary schooling reflects mainly an increase in academic (as opposed to vocational) education, through increased enrollment in academic and teachers' colleges, but without any increase in enrollment in research universities. This is not a surprising result, since those affected by the program are marginal students from low socio-economic backgrounds who would probably not enroll in any academic post secondary schooling if not for the school choice program. It is important to note that these results are general equilibrium in nature, because those affected by the experiment are a very small proportion of their cohort and therefore the expansion in post-secondary schooling in the treated sample is not at the expense of others who could have been 'crowded out' by the new demand for higher education. Furthermore, these effects occurred during a period of expansion of the supply of academic colleges in Israel. Otherwise, the concern of general equilibrium effect will have to be addressed in a context of at scale implementation of such school choice program. Alongside these gains in post-secondary schooling, average annual earnings among treated students 11-13 years after high school graduation increased by 6-7 percent relative to the control group mean. These gains are due to improvements in high school outcomes (matriculation composite score, matriculation diploma, number of matriculation subjects at honor level) and in post secondary schooling attainment, both of which are highly correlated with labor market earnings. Finally, I find that the school choice program did not affect age of marriage and marriage rate but it delayed by half a year the age of having the first child. However, this finding disguises large heterogeneity in the effect on marital outcomes by gender, with significant effects on females and no effect on males.

The lessons learned from this analysis are easily transferable and applicable to other educational settings in developed countries. Both the high school system in Israel and its high-stakes exit exams are very similar to those in other countries. Importantly, variants of the school choice program studied here have been implemented in recent years in developed and developing countries. Another important advantage of the evidence presented in this paper is that school choice can be directly implemented as a public policy, while most recent studies of longer-term outcomes cover measures that are not as easily influenced by policy, such as school or teacher quality.

There is little causal evidence on the long term effect of school choice even though it is a controversial policy. The earlier studies on short term effects of school choice, for example Rouse

long as they are enrolled in seminary (Yeshiva); orthodox Jewish girls are exempt upon request; Arabs are 
(1998) and Cullen, Jacob and Levitt (2006), were followed recently by studies looking at the long term effects, in particular on misbehavior and crime (Deming 2011), and on post-secondary schooling attainment (Demming et al 2013, Chingos and Peterson 2013, Wondratschek et al 2014). Demming et al (2013) study the impact of the public school choice lottery in Charlotte-Mecklenburg schools and find a significant overall increase in college attainment among lottery winners who attend their firstchoice school. Chingos and Peterson (2013) report on an experiment that offered a private-school voucher to low-income families. Overall, this study reports no significant effects on college enrollment of the voucher offer, but they estimate large significant impacts for African-American students and smaller but not statistically significant impacts for Hispanic students. Wondratschek et al (2014) study the short and long term effect of Sweden's 1992 school choice reform, and find it had very small positive effects on marks at the end of compulsory schooling, but it had zero effects on university education, employment, criminal activity and health at age 25 .

The remainder of the paper is as follows. In Section 2 I describe the Tel Aviv school choice program, in section 3 I present the data and in section 4 I outline the identification and econometric model. In Section 5 I present the results and in section 6 some conclusions.

\section{Background}

The analysis of the short and medium term effects, presented in Lavy (2010), indicated that the Tel Aviv school choice program reduced the dropout rate from $7^{\text {th }}$ to $12^{\text {th }}$ grade by $7.3-8.4$ percentage points (a 32 percent decline), increased the matriculation rate by 8 percentage points (a 25 percent increase), and increased the average score in the Bagrut exams by almost 7 points (a 12 percent increase). It also improved the quality of schooling as the number of Bagrut credit units increased by 2 (a 11 percent increase), the number of credits in science subjects increased by one third of a unit (a 13 percent increase), and the number of Bagrut subjects studied at honor level increased by 0.3 (a 13 percent increase). I summarize below the main features of the Tel Aviv school choice program and then examine whether these gains were translated into economically meaningful improvements in adulthood.

\section{The Tel-Aviv school-choice program}

In May 1994, the Israeli Ministry of Education approved a two year trial of the Tel Aviv School Choice Program (TASCP) in the 9th district (see Map 1 in online appendix). It was the first choice program in the country since the 1968 education reform that enacted compulsory integration in grades 7-9. ${ }^{2}$ TASCP was a response to parents' dissatisfaction with students' outcomes and with the

exempt, though some volunteer.

${ }^{2}$ The 1968 reform established a three-tier structure of schooling: primary (grades 1-6), middle (7-9), and high school (10-12). The reform established neighborhood school zoning as the basis of primary enrollment and of the integration and busing of students out of their neighborhoods in middle school. In Tel-Aviv, most middle schools were part of six-year high schools and there were several high schools that only offered the higher grades $\left(10^{\text {th }}-12^{\text {th }}\right)$. 
rigid lack of school choice. Its objectives were to give disadvantaged students access to better schools, facilitate a better match between students and schools, and motivate school productivity improvements through competition. The 9th schooling district included 16 public primary schools 12 secular and 4 religious. Until 1994 the graduates of five of these secular primary schools were bused to one of 5 secondary schools in districts 1-5 in north Tel-Aviv (about 36 percent of the districts' pupils) and a few more of the districts' pupils (5 percent) were enrolled in charter schools outside the district. The graduates of the seven other secular primary schools were assigned to one of the three secondary schools within district $9 .^{3}$

In May 1994 the Tel-Aviv Education Board announced that as of September 1994 this system would be replaced by free choice for the incoming 7th graders, while older cohorts in the district would continue with the old system. The structure of choice was as follows. At the end of sixth grade each student was asked to rank his preferences among the five schools in his choice set, which consisted of the district's three secondary schools and two out of district schools (in districts 1-5 which were the same schools to which students were bused before the program). The choice set varied among students in accordance with the primary school they attended. If there was excess demand for a particular school, students were assigned to schools such that the socio-economic balance of the district was maintained. ${ }^{4}$ The city opened information centers and ran workshops for parents and pupils, and high schools held open days to provide information about the choice program for the incoming 7th grade cohort.

City reports indicate that in the program's first year, 90 percent of students received their first choice and others the remaining 10\% their second. In the second year the first choice rate was even higher $^{5}$, and since 2003 excess demand has been resolved by lottery. Another relevant factor was an expansion of the supply of middle school classes: four high schools, two in district 9 and two in the city's northern districts, which had previously only offered the higher grades (10th-12th), were expanded to offer middle school grades at the commencement of the reform. Despite these changes, over time the choice program led to the expansion of some high schools and to the contraction of others (one school was even closed due to declining enrollment). Enrollment in the city's schools was also affected by the stricter enforcement of the Ministry's rule that pupils were not allowed to attend schools outside of Tel Aviv. Because school budgets were determined according to enrollment, schools that expanded enrollment gained more resources.

The choice program was accompanied by a decision that the city's post-primary schools would have a six grade structure that includes the middle (7th-9th) and higher grades (10th-12th) as part of the same school. In practice this allowed the city to cancel the admission process at the end of

\footnotetext{
${ }^{3}$ These schools were located on the same campus but they were very different in terms of their curriculum and programs offered to students. For example, one included low and high tech vocational schooling.

${ }^{4}$ Siblings in the same school and school capacity were also used as criteria to balance enrollment.

5 The Tel-Aviv Educational Authority (1999).
} 
the 9th grade and to introduce the concept of 'persistence', whereby students automatically enrolled in the 10th grade in the school in which they completed their middle school education. This important component of the reorganization of the school system in Tel Aviv strongly limited the ability of schools to select students into their higher grades based on academic performance. The explicit default became that pupils could remain in the school they chose in the 7th grade for the duration of their secondary education. To overcome this default option, a school had to gain explicit approval from a special city committee: consent was only given in cases where pupils displayed severe behavioral problems and never on the grounds of poor academic performance. This policy change most likely explains a large part of the dramatic decline in the pupil transfer rate in 9th grade, from about 50 percent before the choice program to about 15 percent following it.

In 1996 the experiment was expanded to district 8, in 1998 to district 7, and in the following year to the rest of the city (Tel-Aviv Educational Authority, 2001).

\section{The Israeli high school system}

When entering high school ( $10^{\text {th }}$ grade), students choose whether to enroll in the academic or non-academic track. Students enrolled in the academic track receive a matriculation certificate (Bagrut) if they pass a series of national exams in core and elective subjects taken between $10^{\text {th }}$ and $12^{\text {th }}$ grade. Students choose to be tested at various proficiency levels, with each test awarding one to five credit units per subject, depending on difficulty. Advanced level subjects are those subjects taken at a level of four or five credit units; a minimum of 20 credit units is required to qualify for a Bagrut certificate. About 52 percent of all high school seniors received a Bagrut in the 1999 and 2000 cohorts (Israel Ministry of Education, 2001). The Bagrut is a prerequisite for university admission and receiving it is an economically important educational milestone. For more details on the Israeli high school system, see Abramitzky and Lavy (2014).

\section{The Data}

In this study I use data from administrative files for students in primary schools that were enrolled into the school choice program, pre (sixth graders in 1992 and 1993) and post (sixth graders in 1994) treatment cohorts, and similarly for the control schools, respective pre and post cohorts. The students in the sample completed high school between 1999 and 2001, and in 2013 they are adults, age 29-31. I use several panel datasets available from Israel's National Insurance Institute (NII). The NII is responsible for social security and mandatory health insurance in Israel. NII allows restricted access to this data in their protected research lab. The underlying data sources include: (1) the population registry data, which contains information on marital status, number of children and their birth dates; (2) NII records of postsecondary enrollment from 2000 through 2013 based on annual reports submitted to NII by all post-secondary education institutions, from which we calculated the 
number of years of post-secondary schooling ${ }^{6}$; (3) Israel Tax Authority information on income and earnings of employees and self-employed individuals for 2000-2014; (4) NII records on unemployment benefits, marriage and fertility for the period 2009-2012. The NII linked these data to students' background data that I used in Lavy (2009) to study the effect of the teachers' incentive experiment on high school academic outcomes. This information comes from administrative records of the Ministry of Education on the universe of Israeli primary schools during the 1997-2002 school years. In addition to an individual identifier, and a school and class identifier, it also included the following family-background variables: parental schooling, number of siblings, country of birth, date of immigration if born outside of Israel, ethnicity and a variety of high school and high school achievement measures. This file also included a treatment indicator, school ID and cohort of study. I had restricted access to this data in the NII research lab at the NII headquarters in Jerusalem.

The post high school academic schooling system in Israel: The post high school academic schooling system in Israel includes seven universities (one of which confers only graduate and $\mathrm{PhD}$ degrees), and over 50 colleges that confer academic undergraduate degrees (some of these also give master's degrees). ${ }^{7}$ All universities require a bagrut diploma for enrollment. Most academic colleges also require a bagrut, though some look at specific bagrut diploma components without requiring full certification. For a given field of study, it is typically more difficult to be admitted to a university than to a college. The national university enrollment rates for the cohort of graduating seniors in 1995 (through 2003) was 27.6 percent and the rate for academic colleges was 8.5 percent. ${ }^{8}$

The post-high school outcome variables of interest here are indicators of ever having enrolled in a university and in an academic college as of the 2013 school year, and the number of years of schooling completed in these two types of academic institutions by this date. We measure these two outcomes for our 1999-2001 $12^{\text {th }}$ grade students. Even after accounting for compulsory military service$^{9}$, we expect that most students who enrolled in academic post-high school education, including those who continued beyond the undergraduate level, to have graduated by the 2013 academic year.

Definitions of Outcomes in Adulthood: In this subsection, I describe the outcomes in adulthood for students in the sample. To account for age differences of the different cohorts included

\footnotetext{
6 The NII, which is responsible for the mandatory health insurance tax in Israel, tracks postsecondary enrollment because students pay a lower health insurance tax rate. Postsecondary schools are therefore required to send a list of enrolled students to the NII every year. For the purposes of our project, the NII Research and Planning Division constructed an extract containing the 2001-2013 enrollment status of students in our study.

${ }^{7}$ A 1991 reform sharply increased the supply of postsecondary schooling in Israel by creating publicly funded regional and professional colleges.

8 These data are from the Israel Central Bureau of Statistics, Report on Post-Secondary Schooling of High School Graduates in 1989-1995 (available at:

http://www.cbs.gov.il/publications/h education02/h education h.htm).

${ }^{9}$ Boys serve for three years and girls for two (longer if they take a commission). Ultra-orthodox Jews are exempt from military service as long as they are enrolled in seminary (Yeshiva); orthodox Jewish girls are exempt upon request; Arabs are exempt, though some volunteer.
} 
in the sample, the post-secondary schooling outcomes are also adjusted for years since graduating high school.

Labor Market Outcome. Earnings: Individual earnings data comes from the Israel Tax Authority (ITA). Only individuals with non-zero self-employment earnings are required to file tax returns in Israel, but the ITA has information on annual gross earnings from salaried and non-salaried employment, and they transfer this information, including the number of months of work in a given year, annually to the NII. The NII produces an annual series of total annual earnings from salaries and self-employment and I used this variable for 2000-2014. Following NII practice, individuals with a positive (non-zero) number of months of work and zero or missing value for earnings are assigned zero earnings. $14.1 \%$ of individuals have zero earnings at age 30-32 in our basic sample of 13,142. To account for earnings data outliers I dropped from the sample all observations that are six or more standard deviations away from the mean. Very few observations are dropped from the sample in each of the years and the results are not qualitatively affected by this sample selection procedure. To account for age differences of the different cohorts in the sample, the employment and earnings outcomes are adjusted for years since graduating high school. The same earnings data is also available for the parents of the students in our sample, for the years 2000-2002 and 2008-2012. I compute the average earnings of each parent and of the household for 2000-2002 and use it as an additional control in a robustness check of the evidence presented in this paper. These data were not available for the analysis of the effect of the program on short-term outcomes. Employment: An indicator with value 1 for individuals with non-zero number months of work in a given year, 0 otherwise.

Education. Here as well I measure the outcomes by adjusting for years since graduating high school. University schooling: is an indicator for being enrolled for at least one year in university schooling and years of university schooling is the number of years of attendance during the period 2000-2013. Academic college schooling: is an indicator for being enrolled for at least one year in any academic college and years of college schooling is the number of years of attendance.

Personal Status Outcomes: The data on marital status and having children is available only for 2011. Therefore for these outcomes, we can adjust for years since graduating high school based on information about date of marriage and children's birth dates.

Marriage: is an indicator for being married. Children: is an indicator for having at least one child. Number of Children: is the number of children.

The NII linked these data to students' background data that I used in Lavy (2010) to study the effect of the choice program on high school academic outcomes. ${ }^{10}$ This information comes from

\footnotetext{
${ }^{10}$ As high school outcomes I used an indicator of dropping out before completing twelfth grade, an indicator for matriculation (Bagrut) eligibility, credit-weighted average score on the matriculation exams, number of matriculation credits, number of matriculation credits in science subjects and number of matriculation subjects at honors level. Bagrut eligibility is a prerequisite for admission to higher education in Israel and the average score on the matriculation exams, number of matriculation credits in science subjects and number of
} 
administrative records of the Ministry of Education on the universe of Israeli primary schools during the 1992-1994 school years. In addition to an individual identifier, and a school and class identifier, it also included the following family-background variables: parental schooling, number of siblings, country of birth, date of immigration if born outside of Israel, ethnicity and a variety of high school and Bagrut high school achievement measures. This file also included a treatment indicator, school ID and cohort of study. I had restricted access to this data in the NII research lab at the NII headquarters in Jerusalem.

\section{Identification and Estimation}

In previous work (Lavy 2010) I used difference in differences (DID) and geographical discontinuity in program placement as two alternative methodologies to estimate the effect of the school choice program on short term outcomes (dropout rate) and on medium term outcomes (success at the end of high school, six years after the school choice decision, in high stakes exams). Using DID methodology, I relied on three alternative comparison groups which all yielded almost identical evidence regarding the impact of the choice program. ${ }^{11}$ I therefore use this same identification method to estimate the effect of school choice on long term adulthood outcomes, while combining all three comparison groups into one in order to increase efficiency in the estimation. Results based on using each of these comparison groups separately are in line with the evidence that I present in this paper and are available from the author upon request. I also used in Lavy (2010) geographical discontinuity (GD) in program placement as an alternative identification strategy, which yielded evidence consistent with the evidence based on the DID estimation. I therefore also use this GD identification method in this paper to estimate the effect of school choice on long term adulthood outcomes. I summarize briefly below the comparison group used here in the DID estimation and the group used in the GD estimation. More detail about each of them is provided in Lavy (2010).

The first DID comparison group, based on the gradual implementation of the program, includes school districts in Tel Aviv that were enrolled immediately following the two year experiment. Since all the schools in districts 1-5 were included in the choice sets of students in district 9, only districts 6-8 could serve as a comparison group. Districts 6 and 8 are adjacent to district 9 but their sample of students is too small, therefore I consider district 7 to also be part of the potential comparison group (see Map 1 in online appendix). All three of these districts are part of South Tel Aviv, geographically adjacent to or near district 9, and their population is much more similar to that of district 9 than to that of Northern Tel Aviv (Lavy 2010). The second comparison group includes two adjacent cities east of Tel-Aviv, which are part of the Dan metropolitan area: the Dan metropolitan

matriculation subjects at honors level are used to screen and select students for prestigious universities and sought-after academic programs such as medicine, engineering, and computer science.

${ }^{11}$ In Table A1 in the online appendix I present the mean demographic characteristics of the students in the treatment group and in each of the three alternative control groups used in the DID estimation. This table is a replication of Table 1 in Lavy (2010). 
area covers five major cities, including Tel Aviv. District 9 includes the city's southeastern neighborhoods and is tangential to two of the neighboring cities: Givataim and Ramat-Gan (referred to as GR, see Map 1 in online appendix). GR have independent and separate education systems and therefore were not part of Tel-Aviv's school choice reform. ${ }^{12}$ GR students are very different in mean characteristics from district 9 students (Lavy 2010). However, these differences are very stable as they are similar in 1992 and 1993 as well. The solution, therefore, to the pre-program imbalances is to use data on pre and post program cohorts (panel data) in a difference-in-differences framework that removes time invariant heterogeneity across treated and control groups. Holon is another city adjacent to Tel-Aviv (south) and it is very close to district 9, and I use it as the third comparison group. It is more similar to district 9 in its characteristics than the GR group. ${ }^{13}$

Therefore, the first identification approach that I apply in this paper is based on a contrast between district 9 and a comparison group that includes districts 6-8, RG and Holon, before and after the program was implemented. I use data on pre- and post-program cohorts (panel data) in a difference-in-differences framework that removes any remaining time invariant heterogeneity across treated and control groups. Since this DID estimation compares two consecutive cohorts, and since the program was implemented immediately after it was announced, it is reasonable to assume that the remaining differences were constant within this narrow time range. A concern with this DID approach, however, is that the cohort immediately prior that I use as a control group might be affected through spillover effects at the school level. As these students will be attending the same schools as the treated students, peer effects or competitive effects on school productivity might impact the untreated students as well.

As noted above I also use a geographical discontinuity in program placement as an alternative identification strategy. Following Black (1999), I limit the sample to observations within a narrow band around the municipal border between district 9 and GR (see Map 2 in online appendix). As shown in Lavy (2010), the physical and other characteristics of the communities within this strip (for example, type and average size of homes) are identical, as are zoning laws and municipal (type of property) taxes, which are determined by the central government. Presumably there might still be some differences, such as the political affiliation of the mayor, for example. The concern remains then that such remaining differences may confound the effect of the program. As mentioned above, the use of data on pre- and post-program cohorts in a DID framework will remove such time invariant

\footnotetext{
${ }^{12}$ The Givataim, Ramat-Gan and Holon high school enrollment system before the inception of the TASCP was based on zoning and it has not changed since, nor have these cities undergone any other major educational reform since 1994.

${ }^{13}$ The fact that two alternative sets of DID estimates, one that is based on a comparison group that has much better characteristics and outcomes (GR or Holon) than the treated group and a second that is based on a comparison group that has marginally worse characteristics and outcomes (districts 6-8), yield exactly the same results is reassuring, given the possibility that the DID estimates are biased because of regression to the mean or due to differential time trends in unobserved heterogeneity between treatment and control.
} 
heterogeneity across treatment and control groups. I define this sample based on drawing a symmetric band around the municipal border, 250 or 500 meters on each side. Contrary to the imbalances between district 9 and GR, this GD sample yields better balanced treatment and control groups. In the analysis of the long term outcomes I will use the +/-500 meters band, again in order to have a larger sample for estimation, but it should be noted that the $+/-250$ meters band yields similar results.

\subsection{Estimation}

I first present a controlled comparison of treated and untreated students using samples of pre and post treatment cohorts based on the following regression:

$$
Y_{i j t}=X_{i j t} \beta+Z_{j} d+U_{i j t}
$$

where $Y_{i j t}$ is the ith student's outcome in school $\mathrm{j}$ and year $\mathrm{t} ; X_{i j t}$ is a vector of the same student's characteristics; $Z_{j}$ is the treatment indicator (which equals 1 for district 9 students) and $d$ is the treatment effect. As noted above, I will first estimate the equation using as a comparison group a sample that includes Tel-Aviv district 6-8 students, and GR and Holon students, and then I will also exploit the GD sample (using the +/-500 meters sample).

In addition, I use the before-and-after cross section data as stacked panel data that permits regression analysis with controls for primary-school fixed effects. Therefore, I will estimate stacked models using three years of cross-section data combined. The treatment indicator $Z_{j t}$ is now defined as the interaction between a dummy for the year 1994 and the district 9 indicator, as follows:

$$
Y_{i j t}=\mu_{j}+\pi_{t}+X_{i j t} \beta+Z_{j t} d+\varepsilon_{i j t}
$$

where $\mu_{j}$ is the primary school fixed effect and $\pi_{t}$ is a year (i.e., 1992, 1993 and 1994) fixed effect. Apart from providing a check on the precision of the 1992-1993 vs. 1994 contrast in treatment effects, the introduction of school (fixed) effects also provides an alternative approach to the clustering problem. The validity of this control, however, depends on the validity of an additive conditional mean function as a specification for potential outcomes in the absence of treatment.

\subsection{Descriptive Statistics}

Table 1 presents detailed descriptive statistics of the outcome variables for 11 years since high school graduation for the 1992-1994 cohorts, by treatment and control group and by pre- and post-reform cohorts. Post-secondary enrollment statistics are presented in panel A. The enrollment rate in university schooling in the treatment group for the pre-treatment cohorts (1992 and 1993) is 17.2 percent and for the control group it is 23.1 percent. The difference is $-0.058(\mathrm{se}=0.012)$, and is statistically different from zero. The respective enrollment rates in academic colleges are 20.0 percent and 26.3 percent; the difference is $-0.063(\mathrm{se}=0.012)$ and is statistically different from zero. ${ }^{1415}$ The respective means and estimated differences for the post-treatment cohort are presented in column 4-6.

\footnotetext{
${ }^{\mathbf{1 4}}$ Note that very few students ever enroll in more than one type of post-secondary educational institution.
} 
Note that the mean difference in university enrolment did not change much while the mean difference in the academic college enrolment rate declined to -0.028 from -0.063 . The difference between these two differences (which is a simple uncontrolled difference in difference estimate), 0.035 , will be shown to be very close to the controlled difference in difference estimate that I will present in the next section.

Summary statistics on completed years of schooling are presented in panel B. The average number of years of university completed eleven years after high school graduation in the pre-reform cohorts of the treatment group is 0.683 and in the control group it is 0.974 . The difference is -0.290 $(\mathrm{se}=0.056)$. The respective means for years of college education are 0.555 and 0.822 and the difference is -0.267 ( $\mathrm{se}=0.043$ ). This evidence suggests, as expected, that the treatment-control imbalance at baseline in both types of post-secondary education is in favor of the control group. A similar treatment-control comparison based on the post treatment cohort (1994) reveals that the gap in university attendance remained unchanged while the gap in academic colleges' attendance was almost completely eliminated, and the remaining difference became statistically negligible. The implied simple difference in differences estimate for college is 0.161 years and for university it is -0.040 . These dynamic changes suggest that the program led to improvement in college-going rates and years of college completed without an effect on university outcomes. These estimates are similar to what I will present in the next section based on controlled difference in differences estimation.

Summary statistics for the labor market outcomes are presented in panel C of Table 1. Eleven years after high school graduation, 86.8 and 84.1 percent of the individuals in the pre-treatment cohorts in the treatment and control group, respectively, were employed and the difference between the two was 1.1 percent $(\mathrm{se}=0.010$ ). The respective rates in the post treatment period are $84.1,84.4$ and $-0.003(\mathrm{se}=0.014)$. Average annual earnings at baseline ${ }^{16}$ was lower in the treated group by about NIS 3,000 (\$750), a gap consistent with post-secondary education treatment-control differences.

The summary indicators in panel D suggest that just over half of the treated sample is married by 2011; in the pre-treatment control group this rate is 2 percentage points lower. Age of marriage in the treated group is 25.6 , about a third of a year younger than in the control group and a similar gap is observed in age of having the first child.

In panel E I report statistics on parental income in 2000-2002. This information, which was not available when studying the short and medium term effects of the school choice program, reveals gaps in favor of the control group. This is of course consistent with the other imbalances seen in Table 1: father's income is higher in the pre-program control cohorts by NIS 27,175 and in the post-program by NIS 24,093 and these two differences are not statistically different from each other. The respective

15 The respective means for the whole cohort (82,500 students) are 24.0 in universities and 24.0 percent in academic colleges.

${ }^{16}$ The mean earnings in this sample, NIS70,639, is identical to mean earnings in the whole cohort, NIS 70,300. 
differences between average mother's earnings are NIS -10,904 and NIS -7,974. These stable differences will be shown not to affect the treatment effect estimates of school choices when added as controls in the difference-in-differences regressions.

\section{Empirical Evidence}

The school choice program had positive and significant short and medium term effects on students' high school completion rate and on academic achievements during high school. Across identification methods and comparison groups, the results consistently suggest school choice significantly reduced the drop-out rate by 8.4 percent (35 percent decline) and increased the matriculation rate by 6.1 percentage points ( 25 percent improvement). These results are presented in Table A1 in the online appendix. These very large effects were accompanied by an improvement in the quality of schooling. The average number of Bagrut credits increased by two units relative to the pre-program mean of 12 units and the average score in all of the Bagrut exams was up by 6.6 points, about 10 percent improvement. Other dimensions of quality improvement are the increase in number of Bagrut credits in science subjects and the increase in Bagrut honor level studies (up by a quarter relative to a mean of one such subject). These estimates are also presented in Table A1. The estimates based on the GD sample are presented in Table A2 and reveal a similar pattern of a positive effect of the school choice program on high school outcomes.

In Lavy (2010) I also provided evidence about potential mechanisms of the effect of school choice on the short and medium term academic outcomes. This analysis shows that school choice improved the learning and social environment in school. For example, as a result of the program, teacher-student relationships and students' social acclimation and satisfaction at school improved and the level of violence, bulling and classroom disruptions declined. The higher satisfaction of students at school can probably be attributed to a better match between students and schools, an improvement facilitated by the school choice program. Indirect evidence of the improved matching is the fact that a large proportion of district 9 students who had the longest travel distance from home to schools in districts 1-4, opted out as well, and chose out of district schools. This is evidence of the willingness of students to enroll in what they perceive to be a better school, even at the expense of longer travel time and higher cost. Also shown in Lavy (2010) is that competition among schools intensified following school choice and that it led to improved school quality. For example, two schools that experienced sharp decline in enrollment were closed while others expanded. Improved quality was facilitated by the flexibility that schools enjoyed with respect to curriculum and programs. For example, some schools introduced new programs such as enrollment in university courses. However, conclusions about whether free school choice improves real human capital accumulation and well-being can only be based on longer term effects, in particular outcomes such as post-secondary enrollment and completed years of tertiary education, employment, earnings, welfare dependency and other social outcomes. We study these next. 


\subsection{Effect on Post-Secondary Schooling Attainment}

I first present graphs illustrating the effect of the school choice program on post-secondary education. I focus on the two sub-sectors of academic post-secondary education in Israel. The first includes the seven research universities in Israel that confer $\mathrm{BA}, \mathrm{MA}$ and $\mathrm{PhD}$ degrees. These universities require a matriculation diploma for admission, including an intermediate or advanced matriculation unit in English ${ }^{17}$ and at least one matriculation subject at an advanced level. About 35\% of all students are enrolled in one of the seven universities. The second sub-sector is made up of more than 50 academic colleges that mostly confer a BA degree and predominantly offer social sciences, business and law degrees.

Figure 1 presents the dynamic of the treatment effect on academic college enrollment (vertical axis) starting from the first year after high school graduation until 12 years later (horizontal axis). We note again that during the first few years after high school graduation almost all boys (for three years) and most girls (for two years) are still in military service and therefore the treatment effect is not informative because it is based on a limited sample of those not drafted to service. This treatment effect is however positive and statistically significant from year four after graduating high school, reaching a high of 4.8 percent and declining slightly towards the end of the period to 4 percent. The respective mean enrollment rate for the treated group increases gradually from year one and is highest at 21 percent twelve years later. The effect size here is therefore a 20 percent increase. The effect on completed years of academic college (presented in Figure 1A) increases continuously until 12 years after graduating high school, reaching a peak at 0.19 years and leveling thereafter. The mean of completed years of academic college in the treatment group is 0.6 and therefore the effect size is a 30 percent increase.

Figures 2 and 2A present the estimated effects on university enrollment and attainment and the pattern revealed in these figures is very different, as the effect is practically zero. The treated group mean of university enrollment rate is 0.18 and the mean years of university is 0.71 years, and both of these outcomes are not changed due to the program.

In Figures 3-3A I replicated this graphical analysis for any type of post-secondary education (including teachers colleges and non-academic education) and the results are very similar to those presented in Figures 1-1A. Overall post-secondary enrollment increased by almost 5 percentage points and total education increased by a fifth of a year. ${ }^{18}$

Table 2 presents detailed estimates from regressions of the effect of free school choice on post-secondary education attainment when outcomes are measured twelve years after high school graduation. The first row presents DID estimated effect on enrollment in any type of post-secondary

\footnotetext{
${ }^{17}$ To qualify for a matriculation diploma a basic study program in English is sufficient, but university admission requires a higher level.

${ }^{18}$ It is important to note here that the expansion in enrollment in academic colleges due to the school choice program could not have been at the expense of other students because the choice program and the number of students affected was very small relative to the overall enrollment in academic colleges in the whole country.
} 
education (column 2) and on the respective completed years of education (column 4). Standard errors appear below each estimate in brackets and are clustered by secondary school. School choice enrollment in any post-secondary education increased by 4.6 percentage points relative to a preprogram mean of 42.5 percent in treated schools and 52.9 percent in the control group. The effect on completed years of education (column 4) is 0.187 ( $\mathrm{SE}=0.089$ ). Relative to the pre-choice treatment group mean (1.648) this is a 15 percent gain.

It is interesting and important to know what types of post-secondary education are affected. Since the treated population is from a low socio-economic background with relatively low enrollment at the higher quality end of academic institutions, we expect the effect to be low on university education and higher on colleges and non-academic post-secondary institutions. In the second row I present the estimated effect on university education and in the third row the effect on education in academic colleges. The effect on university enrollment is practically zero $(0.006, \mathrm{SE}=0.014)$ and so is the effect on university years of education. The effect on academic college enrollment is however up by 4 percent, significantly different from zero $(\mathrm{t}=2.2)$, and completed years of this type of education increased also, by almost a fifth of a year $(0.171, \mathrm{SE}=0.050) .{ }^{19}$ The gain in academic college education is almost equal to the overall gain in any type of post-secondary education, indicating that the effect on any other type of education is very small or zero. ${ }^{2021}$

The evidence presented above clearly demonstrates that the gain in post-secondary education is concentrated in the lower end of academic education in Israel. The academic colleges are less prestigious than universities and their admission requirements are less demanding in terms of Bagrut results. This pattern is perhaps expected because the treated population is mostly from a disadvantaged segment of the Israeli population and their enrollment and years of study in university is much lower than the overall mean in the country. In addition, we can safely claim that the affected students are at the margin of being admitted to post-secondary education, which can also explain why the treatment effect is concentrated at the lower end of the quality distribution of academic education in Israel.

The long term data that I use in this paper includes information on parental income during the years of the experiment. It allows me to assess how sensitive the post-secondary treatment estimates are to adding controls for family earnings. The estimates presented in Table A3 in the online appendix

\footnotetext{
${ }^{19}$ It is important to note here that the expansion in enrollment in academic colleges due to the school choice program could not have been at the expense of other students because the choice program and the number of students affected was very small relative to the overall enrollment in academic colleges in the whole country.

${ }^{20}$ Indeed enrollment in teachers' colleges also increased, by 2.7 percent and significantly different from zero, but the respective increase in years of this type of education is positive but small and imprecisely measured. Enrollment and years of schooling in vocational education (two-year colleges that confer practical engineering degrees) declined by 1.5 percentage points and by 0.025 years, very small and imprecisely measured changes. These results are not presented in the paper and are available from the author.

${ }^{21}$ In results not shown here I estimated placebo effects based on a contrast between the two untreated cohorts of 1992 and 1993. Overall, these controlled experiment estimates are not significantly different from zero, similar to respective placebo regression estimates with high school outcomes as the dependent variables (Lavy 2010).
} 
show that adding to the difference-in-differences regression a control for family income (average in 2000-2002) does not change at all the point estimates relative to those presented in Table 2. For example, the estimated effect on college enrollment in Table A3 is 0.041 and on college years of education it is 0.170 , almost identical to the respective estimates in Table 2 . This is a remarkable result given that the treatment and control samples are not balanced in family income, but they are equally imbalanced in this dimension, as in others, for the pre- and post-treatment cohorts.

To further check the robustness of the evidence presented above, I use the GD design described in the previous section. The GD sample includes observations within a relatively narrow band around the municipal border between district 9 and GR and the descriptive statistics of the control and treatment group in this sample are presented in Table 3. It is important to note that in this sample, the treated group is from a much higher socio-economic status and it resembles more closely the control group. For example, the mean of fathers' and mothers' years of education in the GD treated sample in the 1993 cohort is 11.43 and 11.58, respectively, while in the rest of district 9 the respective means are less than 10. A similar pattern is observed for the post-secondary educational outcomes presented in Table 3, where in the GD treated sample the mean enrollment in university and academic college education in the post treatment cohort (1994) is 22.6 and 24.7 percent, respectively, while the respective means in the rest of district 9 are 17.9 and 20.9 percent, respectively. The much higher socio-economic status of treated students in the GD sample in comparison to the rest of district 9 suggests that we might expect a higher effect of school choice on university schooling than what we estimated based on district 9's full sample.

Indeed this is the case, as shown in Table 4 where I report estimates derived from the GD sample. The effect on university enrollment is 0.051 and the effect on academic college enrollment is -0.011 . The effect on years of university education is 0.260 and the effect on academic college years of education is 0.017 . This pattern is strikingly different from the evidence that is based on all of district 9. However, these estimates are less precisely measured than the respective estimates in Table 2 , most likely because of the much smaller sample size. As we will see below, the gain in university education will be rewarded with a higher increase in annual earnings relative to the gain in annual earnings experienced by those who improved only academic college education.

\subsection{Effect on Employment and Earnings}

We start here as well with a graphical presentation of the impact of the school choice program on employment and earnings. Again we measure for each individual these two outcomes based on number of years since graduating high school. The employment and earnings data are available until year 2014, so thirteen years is the longest period after graduating high school for which we examine the effect of the program. Figure 4 presents the yearly estimates on employment. As noted earlier, the estimates for the first three years are not meaningful because most of the students in our sample were still in military service. In the fourth year after high school graduation, about 85 percent of the 
individuals in the sample were employed (according to our definition of employment, which is employed at least for one month during the year and had positive earnings). For almost all years the estimates are not precisely measured: for 5-7 years after high school graduation the estimates are positive and thereafter they are negative, but in most years they are not statistically different from zero, especially in 12 and 13 years after high school graduation. Similar evidence is obtained for the outcome that measures the number of months per year of being gainfully employed. These imprecise and inconclusive employment dynamics imply that they do not play an important role in determining the change in earnings due to the school choice program.

We next turn to the time series of estimated effects on annual earnings, which are presented in Figure 5. The treatment effect estimates on earnings are positive throughout the period after high school graduation. They increase over time monotonically with the exception of a spike in treatment effect nine years after high school graduation. Similarly, average annual earnings in the sample also increase monotonically until the end of the period, from NIS 40,000 (about $\$ 10,000$ ) five years after high school graduation to just over NIS 80,000 13 years after high school graduation. The treatment effect on earnings in the last two periods of analysis is just below NIS 5,500 a year and it is significantly different from zero at the 10 percent level of significance in both periods. It is interesting to note that the earnings treatment effect is not negative even in the period when post-secondary enrollment rate is higher among treated students. This pattern is different from that reported in Lavy (2016), where teacher pay for performance increased university education while lowering employment and earnings during the three to five years when students are studying. This contrasting pattern is not surprising for several reasons. First, it is typical that students in academic colleges in Israel work part time or full time, while university studies have a more demanding academic schedule and requirements that correspond to full time attendance, making it more difficult to combine work with study. Secondly, the treated students in academic colleges are usually from a lower socioeconomic background in comparison to students in universities, and therefore they can rely less on parental support. Thirdly, scholarships based on academic merit and on low family income are available for university students but not for students in academic colleges.

Table 5 presents evidence about the effect of the school choice program on employment, number of moths worked in a year, and monthly earnings, for 11 to 13 years after high school graduation (columns 2, 4,6) and based on stacking the three periods in one sample (columns 8). The average employment rate in the treatment group in these three periods is 87.0, 85.2 and 85.4, respectively. The respective treatment effect on employment is negative, though it is small and practically not different from zero in the last two periods. The estimated effect on months worked per year has the same pattern. It is important to note that the negative though small employment effect does not reflect a higher rate of individuals still studying among treated students; the proportion of students in the 1994 cohort who are not yet employed and are still studying is the same in both 
groups: in the treatment group in 2012 it is 1.4 percent and in the control group it is 1.3 percent. The respective means in the 1992-93 cohorts are 0.7 percent and 0.8 percent.

The average annual earnings for the 1992-1993 cohorts in treated schools 11 years after high school graduation is NIS 74,709 $(\$ 17,620), 12$ years after high school graduation it is NIS 78,313 $(\$ 19,216)$ and 13 years after high school graduation it is NIS 81,230 (\$21,377). The estimated effect of the school choice program on annual earnings is NIS 3,368 (\$935) 11 years after high school graduation, NIS 5,544 12 years after and 5,662 13 years after. The last two estimates are significantly different from zero at the 5 percent level of significance. I also estimated an earnings effect using a combined 11 to 13 years after high school graduation earnings, stacking the data together for these three periods. This estimate is presented in column 8 of Table 5. The estimated effect of school choice on earnings from this stacked data is NIS 4,763, close to the average of the estimates in these three years.

In Table A4 in the online appendix I present the treatment estimates on earnings and employment when controls are added for parental or family earnings. The three columns correspond to estimates for 11, 12 and 13 years after high school graduation. These estimates of the treatment effect of the program are very similar to the estimates presented in Table 5. The obvious conclusion is that adding a control for parental earnings does not affect at all the treatment estimates of the effect of school choice on labor market outcomes.

In Table 6 I present the estimated effect on labor market outcomes based on the GD sample. The effect on earnings has the same pattern as in Table 5 but the estimates are larger. Focusing on the stacked data estimates in column 8 , the annual earnings gain during 11 to 13 years since high school graduation is NIS 7,613: a 9 percent gain relative to total annual earnings in this period. The larger gain estimated based on the GD sample reflects to some extent the higher increase in years of postsecondary education and the higher rate of return for university education in Israel relative to the rate of return to academic college education. Caplan et al (2009) report that in many fields of study, academic college graduates in their first jobs earn on average 20 to 30 percent less than university graduates. However, the effect on employment is negative and larger than what is observed in the full sample. This is a puzzling pattern that is resolved when I estimated all treatment effects by gender which show that all of the negative effect on employment is on women, and that most of the positive effect on earnings is due to men. Consistent with these results is the positive effect on women's marriage rate and fertility without a corresponding effect on men. I present more background to these results in the sections where I report results by gender, and the marriage and fertility effect of school choice.

\section{Comparing the Effect on Earnings to Related Evidence}

This is the first study to provide evidence of the effect of school choice on students' earnings at adulthood. However, it is still useful to compare our results to the impact of other childhood and education interventions on earnings at adulthood. Andersson et al. (2013) estimated that living during 
teenage hood in public or voucher housing increased females earnings by $18-21$ percent. Each additional year of public or voucher-supported housing increases earnings by 7 percent for females. For males each year of public housing participation as a teenager increases adult earnings by 5 percent with no corresponding effect of voucher housing. Chetty et al. (2011) have shown that having a kindergarten teacher with more than ten years of experience increased students' average annual earnings at ages 25 to 27 by 6.9 percent $(\$ 1,093)$ between 2005 and 2007. Similarly, an improvement in class quality increased average annual income earned between ages 25 and 27. Johnson et al. (forthcoming QJE) show that for children from low-income families, increasing per-pupil spending by 10 percent in all 12 school-age years increased adult hourly wages by 13 percent. Schweinhart et al. analyze the long term effect of the High/Scope Perry Preschool experiment and find that students in treatment had significantly higher median annual earnings than the no-program group: 20 percent higher at age 27 and by 36 percent higher at age 40. Finally, Chetty, Hendren and Katz (2016) find that moving to a lower-poverty neighborhood (MTO) significantly improves college attendance rates - by 2.5 percent - and earnings by 31 percent, for children who were young (below age 13) when their families moved. Clearly our estimated effects on earnings are not unusually high relative to estimates surveyed above. For example, the teachers' pay experiment raised college enrollment by 5 percent, twice that of the MTO effect, and increased earnings 10-12 years after high school graduation by 7-9 percent, a quarter of the MTO effect.

\section{What Explains the Increase in Earnings?}

Note that if we assume that all of the 6 percent average increase in annual earnings 11-13 years after high school graduation (based on the DID estimates using the full sample and stacked data) is due to the 0.2 increase in years of schooling, this would imply a much higher rate of return to a year of schooling estimated in recent studies in Israel (Frisch and Moalem 1999, Frisch 2007). ${ }^{22}$ However, as shown above, treated students experienced a range of improvements in educational outcomes that are likely to be rewarded in the labor market independently of the return to post-secondary years of schooling. Particularly important is the matriculation rate, which increased by 6-7 percent and earns a return of about 13 percent independently of the return to years of schooling. ${ }^{23}$ In addition, the quality improvements in the matriculation study program and diploma (for example, the average score, number of credit units and credits in honor and science subjects) could also be rewarded in the labor market beyond the return to years of schooling. ${ }^{24}$ The program also led to improvements in some non-

\footnotetext{
${ }^{22}$ It should be noted that the sample used in this analysis includes individuals with zero earnings. Therefore the estimated impact on earnings could also reflect an indirect effect through an effect on employment, while a classic Mincer rate of return to schooling regression does not include individuals with zero earnings. However, the evidence in Table 5 did not reveal any effect on employment.

${ }^{23}$ For example, Angrist and Lavy (2009) estimate that Bagrut holders earn 13 percent more than other individuals with exactly 12 years of schooling.

${ }^{24}$ Caplan et al (2009) demonstrate that earnings in Israel are highly positively correlated with the quality of post-secondary schooling (colleges versus universities and higher versus lower quality universities). For
} 
cognitive behavioral outcomes, for example it reduced the level of violence and classroom disruption, improved teacher-student relationships and increased students' social acclimation and satisfaction at school. These effects suggest that the program improved students' social kills, and recent evidence suggests that the labor market increasingly rewards such skills. ${ }^{25}$

The interesting question therefore is whether the gains experienced by students due to the access to free school choice (particularly the increase in academic college entry, completed years of education and the higher earnings at adulthood) could be predicted by the short- and medium-term positive effects of school choice on Bagrut outcomes? That is, are the effects measured at the time of the experiment predictive of the program's long-term effects? Do Bagrut outcomes that measure quality of study program play an equal role in this regard? It should be noted however that we can address this question but we cannot decompose the effect on earnings of Bagrut outcomes to the component that operates through its effect on post-secondary schooling and the part that reflects a direct independent effect unrelated to post-secondary schooling.

We approach this question by first estimating OLS regressions of annual earnings on the various high school educational outcomes, while including in the regression controls for student's parental and demographic characteristics. In these regressions we use a sample that includes only the control group from the two pre-reform years. These results are presented in Table A5 in the online appendix. Using data for 13 years after high school graduation, I report in panel A estimates from regressions when only one of the high school outcomes is included in the regressions (columns 2) and also estimates when all outcomes are included jointly in the regression (columns 3). When included one at a time, estimates of all outcomes are positive and very precisely measured. When all four are included jointly, all outcomes (the average matriculation score, the indicator of obtaining a matriculation diploma, the overall number of matriculation credits and units in science subjects) remain positive and statistically significant, though the point estimates are smaller - as expected due to high collinearity among these variables. These results are consistent with evidence reported in Lavy, Ebenstein and Roth (2014) and Ebenstein, Lavy and Roth (2016) who use random shocks to performance in matriculation exams to identify the reduced form effects of these high school outcomes on earnings at adulthood, and find strong and significant positive effects.

In panel B column 2, I report estimates from regressions of the post-secondary enrollment and completed years outcomes on earnings 13 years after high school graduation, first when including only one outcome at a time (column 2), and secondly where all four are included jointly (column 3). Here as well each of these outcomes have positive and significant association with earnings, and when included jointly all four are positive but only three of them are statistically significant. In column 4, I

example, this study shows that earnings are much higher for graduates of Tel Aviv, Jerusalem and the Technion Universities relative to graduates from the other four universities in the country. Admission to the top universities is of course positively correlated with the high school matriculation outcomes.

${ }^{25}$ See for example Deming (2015). 
report the estimates from a regression where all high school and post-secondary education outcomes are included jointly. Note that six of the eight outcomes still have positive and significant estimated coefficients and that three of the high school outcomes are among them, even though the regression includes the post-secondary schooling variables. I view this as evidence that the high school outcomes that measure quality of education have an effect on earnings in addition to their effect on postsecondary schooling. A second conclusion from Table A5 is that high school and post-secondary schooling outcomes are indeed correlated with earnings.

Another way to check whether the program's effect on earnings stems from improvement in schooling outcomes is to examine whether the estimated effect on post-secondary attainment and earnings shrinks or even disappears when the Bagrut outcomes are added as controls. Of course, such evidence could be only suggestive because the high school outcomes are endogenous and are probably correlated with the error term in the regressions of long term outcomes. In Table 7 I present estimates of the coefficient of the school choice treatment effect in a DID regression that includes also the high-school outcomes as explanatory variables - first including one at a time and secondly all four jointly. For ease of comparison, I present in column 1 the original treatment effect estimates from Tables 2 and 6. The effect of school choice on enrollment in any post-secondary schooling is 0.040 . The inclusion of each of the high-school outcomes as an additional control shrinks the treatment effect two thirds towards zero, with the exception of number of Bagrut science credit units. When all four high school outcomes are included, the treatment effect estimate falls to 0.013 and it is not statistically different from zero (first row-column 6). A similar pattern is seen in the second row of Table 7, when the long term outcome is completed years of college schooling: the treatment effect declines from 0.171 to 0.079 . However, the most striking result is the sensitivity of the treatment effect on earnings to adding the high school outcomes as controls: the average matriculation score and the number of matriculation credits reduce the treatment effect from NIS 4,763 to just over 600, an 87 percent decline. When all four high school outcomes are added to the regression as control, the earnings effect declines to 79 , though it has a large standard error. Similar results are obtained when the GD sample is used.

\section{Effect of School Choice by Gender}

Previous research on the effectiveness of schooling interventions has shown differences in the responsiveness of boys relative to girls (for example, Angrist and Lavy 2009). To test for this possibility, in Table 8 , I stratify the sample based on the gender of students and present first the effect of school choice on high school outcomes, by gender. ${ }^{26}$ Free school choice improved all five outcomes for boys and girls except the dropout rate of girls, which declined by only 2.1 percentage points, with a t statistic of just 1.5 . However, it is noticeable that girls have higher means in all six high school outcomes and girls' dropout rate is much lower than that of boys, 10.3 percent versus 26.6 
percent among boys in the sample. However, all of the point estimates suggest that the effects are larger among boys except for the effect on the matriculation rate. The gender differences are statistically significant for the following outcomes: dropout rate, average score, number of credits, number of subjects studied at honor classes.

In Table 9 I report the estimated effects of school choice on post-secondary schooling outcomes by gender. Boys gained a 9.3 percentage increase in enrollment and a third of a year of post-secondary schooling, most of it in academic colleges but some in university. The girls' gain is limited to academic colleges, but the estimated effect is much smaller than that for boys. Table 10 shows that these gender differences are also reflected in the labor market. Focusing on the estimates based on the stacked regressions that pool data for the period 11-13 years after high school graduation, the effect on boys' earnings is NIS $6,807(\mathrm{se}=3,615)$, an 8 percent increase, while the earnings effect for girls is NIS $1,785(\mathrm{se}=2,136)$, which is not statistically different from zero. However, the girls' labor market experience includes also a 3.1 percent decline in employment rate and a two thirds of a month decline in months of work in a given year. Both these effects are precisely measured. The decline in months of work among treated girls accounts for a negative NIS 4,931 (= $[(68,347 / 9.288) \times 0.671)])$ effect, which wipes out the expected positive effect of the increase in college education on earnings. On the other hand, the effect on boys' employment is practically zero. What can explain the different pattern of the labor market effects by gender, in particular the negative effect on girls' employment? I turn in the next section to the effect on marriage and fertility outcomes, which provides partial answers to this puzzle.

\subsection{Effect on marriage and children}

In Table 11 I report results regarding the program's effect on marriage and fertility. The marriage and fertility data is available up to 2011. However, I can still compute these outcomes by years after high school graduation because the dates of marriage and of birth of children are available in the data. Fifty six percent of the treated sample are married after ten years following high school graduation. The treatment effect on being married at this date is 2.8 percent but it is not precisely measured. The age of marriage effect is similar $(0.125, \mathrm{se}=0.151)$. The estimated effects on the indicator of having children and on the number of children are positive, but they are not measured precisely. However, the age of having the first child is delayed by half a year and this effect is precisely measured with $\mathrm{SE}=0.174$.

In columns 4 and 6 I present the respective effects on boys and girls and meaningful differences are revealed. School choice has a negative though imprecise effect on boys' marriage rate and it has a large positive effect on girls' marriage rate, which is 8.1 percent higher relative to a mean of 62.9 percent. Age of first marriage of girls is unchanged while it is delayed by a third of a year for boys. The probability of having children by age 28 is increased for girls by 8.8 percent, relative to a

${ }^{26}$ These results are not reported in Lavy (2010). 
mean of 51.8 percent, while the effect for boys is negative. The effect on number of children is positive for girls, up by 0.158 children, while for boys it is negative, a decline of 0.102 children. All the estimated effects on girls are statistically significant and so are some of the estimated effects on boys. The higher marriage and fertility rates among women in the treated sample could be related to the lower employment and earnings gains of this group, even though they had higher means of end of high school and post-secondary schooling outcomes relative to untreated women in the sample.

Of course, marriage and fertility are endogenous choice variables, and therefore it is not possible to study the school choice effect by samples stratified by marriage and parenting status. Yet it is interesting to note that married women in our sample, both in treatment and in the control group, have lower employment rate and lower earnings. A comparison of married women in the treated group and the control group did not yield any differences in spouse's mean education and earnings, ruling out the possibility that own education and earnings were substituted by the spouse's outcomes through marriage. I of course caution again that stratification of the sample by these choice variables is not legitimate and therefore this evidence is only suggestive of potential links among outcomes.

\section{Conclusions}

The vast majority of published research on the impact of school interventions has examined their effects on short-run outcomes, primarily by looking at their impact on standardized test scores. While important, a possibly deeper question is the impact of such interventions on life outcomes in the long-run. This is a critical question because the ultimate goal of education is to improve lifetime well-being. Therefore, gaining new insights about which interventions are more effective in improving long-term outcomes will make a potent contribution to the design and implementation of new interventions, better resource allocation and the efficiency of the education sector.

Recent research has begun to look at this issue, but much work remains to be done, particularly with regard to the long-term effects of interventions explicitly targeting improvement in the general quality of education and students' educational attainment. The empirical evidence from this study contributes to a more complete picture of the long term returns to various educational interventions. This effort should enable teachers, institutions and governments to make more informed decisions as to which educational programs constitute the most beneficial use of limited school resources. The high school system in Israel and its high-stakes exit exams are very similar to those in other countries, and the school choice program studied in this paper shares many features with programs implemented in recent years in the US and in European and other OECD countries. As a result, the lessons learned from this research are transferable and applicable to the education system in other developed countries.

The school choice program studied here had positive longer term outcomes at adulthood. The evidence clearly suggests that allowing children to choose their secondary school freely at age 12 , not only improved sharply their high school outcomes six years later, but it also impacted positively their 
path to post-secondary schooling and increased meaningfully their earnings about a decade and a half later. It is important to note also that these gains were not at the expense of other students in the receiving schools, because this later group was already exposed to a similar proportion of incoming students as a result of the bussing program that preceded the school choice program. If such a peer effect was operational it should have been positive, because the opting out to schools outside the own school district was voluntary in the choice program while being compulsory during the bussing program. In earlier work I have shown that the improved outcomes during middle school and high school were facilitated by a better student-school match, by more competition among schools and by higher schooling quality. These results are important because the school choice experiment targeted a disadvantaged population in some of the more deprived parts of Tel Aviv. Since evidence about the Tel Aviv school choice program has become available, other school choice programs were introduced, for example in Jerusalem in 2006 and more recently in many cities in Israel. ${ }^{27}$

\section{References}

Abramitzky Ran and Victor Lavy. 2014. "How Responsive is Investment in Schooling to Changes in Returns? Evidence from an Unusual Pay Reform in Israel's Kibbutzim", Econometrica, Vol. 82, No. 4 (July), 1241-1272.

Angrist Josh and Victor Lavy. 1999. "Using Maimonides' Rule to Estimate the Effect of Class Size on Children's Academic Achievement." Quarterly Journal of Economics, Vol. 114 No. 2 (May), 533-575.

Acemoglu, Daron and David H. Autor. 2010. "Skills, Tasks and Technologies: Implications for Employment and Earnings." In Orley Ashenfelter and David Card, eds., Handbook of Labor Economics, Elsevier, Vol. 4B, 1043-1171.

Anderson, Michael L. 2008. "Multiple Inference and Gender Differences in the Effects of Early Intervention: A Reevaluation of the Abecedarian, Perry Preschool, and Early Training Projects," Journal of the American Statistical Association, 103 (484), 1481-1495.

Black, Sandra. 1999. "Do Better Schools Matter? Parental Valuation of Elementary Education," Quarterly Journal of Economics, 114(2), May: 577-99.

\footnotetext{
${ }^{27}$ The Ministries of Education and of Finance in Israel recently introduced a large school choice program that includes about 15 of the largest cities in the country. As this recent expansion is reaching a nationwide scale, issues of general equilibrium effects become important, in particular with regard to whether the higher education system in Israel can accommodate the expected increased demand for post-secondary schooling. In this regard it is important to note that the creation of academic colleges that started in the mid 1990's has gained momentum and in the following two decades more such colleges were opened all over the country. This large supply expansion and the existing excess capacity in most of these colleges will be able to accommodate the increase in demand for higher education due to a country wide school choice program, without repercussions for the existing demand.
} 
Caplan Tom, Orly Furman, Dmitri Romanov. 2009. Noam Zussman "The Quality of Israeli Academic Institutions: What the Wages of Graduates Tell About It?" Central Bureau of Statistics, Israel, WP NO. 42, May.

Chetty, R., J. Friedman, N. Hilger, E. Saez, D. Whithmore Schanzenbach, and D. Yagan. 2011. "How Does Your Kindergarten Classroom Affect Your Earnings? Evidence from Project Star," Quarterly Journal of Economics 126(4): 1593-1660.

Chetty, R., J., John Friedman and Jonah Rockoff, 2014, "Measuring the Impact of Teachers II: Teacher Value-Added and Student Outcomes in Adulthood", American Economic Review 104(9): 2633-2679.

Chetty, Raj, Nathaniel Hendren, Patrick Kline, and Emmanuel Saez, "Where is the Land of Opportunity? The Geography of Intergenerational Mobility in the United States" Quarterly Journal of Economics 129(4): 1553-1623, 2014.

Chingos M. Matthew and Paul E. Peterson. 2013. "Experimentally Estimated Impacts of a School Choice Intervention on Long-Term Educational Outcomes: The Effects of School Vouchers on College Enrollment". Working Paper, July, Program on Education Policy and Governance, Harvard University.

Cullen, J. B., Jacob, B.A., and Levitt, S.D. 2006. "The Effect of School Choice on Student Outcomes: Evidence from Randomized Lotteries," Econometrica, 74(5):1191-1230.

Deming, David. 2009. "Early Childhood Intervention and Life-Cycle Skill Development: Evidence from Head Start," American Economic Journal: Applied Economics, 1 (3), 111-134.

Deming, David J. 2011. “Better Schools, Less Crime?” Quarterly Journal of Economics 126 (4): 2063-115.

Deming David, S. Cohodes, J. Jennings, and C. Jencks. 2013. "School Accountability, Postsecondary Attainment and Earnings." NBER WP. w19444.

Deming, David J., Justine S. Hastings, Thomas J. Kane, and Douglas O. Staiger. 2014. "School Choice, School Quality, and Postsecondary Attainment." American Economic Review, 104(3): 991-1013.

Deming DJ, Billings S, Rockoff J. 2014, "School Resegregation, Educational Attainment and Crime: Evidence from the End of Busing in Charlotte-Mecklenburg". Quarterly Journal of Economics. 2014; 129(1):435-476.

Deming J. David, 2015, “The Growing Importance of Social Skills in the LABOR Market”. Draft, Harvard School of Education.

Dustmann C., P. Puhani and U. Schonberg. 2012. "The Long-Term Effects of School Quality on Labor Market Outcomes and Educational Attainment", Draft, UCL department of economics, January. 
Dynarski, S., J. Hyman, and D. Whitmore Schanzenbach. 2013. "Experimental Evidence on the Effect of Childhood Investments on Postsecondary Attainment and Degree Completion" Journal of Policy Analysis and Management, 32(4).

Frisch, R. 2007. "The Return to Schooling - the Causal Link Between Schooling and Earnings," Working Paper 2007.03, Research Department, Bank of Israel. [1244]

Frisch, R., and J. Moalem. (1999). "The Rise in the Return to Schooling in Israel in 1976-1997," Working Paper 99.06, Research Department, Bank of Israel. [1244]

Garces, E., D. Thomas, and J. Currie. 2002. "Longer-Term Effects of Head Start," American Economic Review, 999-1012.

Heckman, James J. and Paul A. LaFontaine. 2010. "The American High School Graduation Rate: Trends and Levels." The Review of Economics and Statistics, 92(2): 244-262.

Johnson, Rucker C., C. Kirabo Jackson and Claudia Persico "The Effects of School Spending on Educational and Economic Outcomes: Evidence from School Finance Reforms," The Quarterly Journal of Economics (forthcoming).

Lavy, Victor. 2010. "Effects of Free Choice among Public Schools." Review of Economic Studies, October, 77, 1164-1191.

Lavy, Victor. "Teachers' Pay for Performance in the Long-Run: The Dynamic Pattern of Treatment Effects on Students' Educational and Labor Market Outcomes in Adulthood”. NBER WP, 2016.

Lavy Victor, Avraham Ebenstein and Sefi Roth. "The Long Run Human Capital and Economic Consequences of High-Stakes Examinations”. NBER WP 20647, 2014.

Lavy Victor, Avraham Ebenstein and Sefi Roth. )2016) “The Long Run Economic Consequences of High-Stakes Examinations: Evidence from Transitory Variation in Pollution". American Economic Journal: Applied Economics, 8(4): 36-65.

Ludwig, Jens and Douglas L. Miller. 2007. "Does Head Start Improve Children's Life Chances?

Evidence from a Regression Discontinuity Design," The Quarterly Journal of Economics, 122 (1), 159-208.

Rouse, C. E. 1998. "Private School Vouchers and Student Achievement: an Evaluation of the Milwaukee Parental Choice Program," Quarterly Journal of Economics, 118, 553-602.

Schweinhart, L., J. Montie, Z. Xiang, W.S. Barnett, C.R. Belfeld, and Milagros Nores. 2005. "Lifetime effects: The High/Scope Perry Preschool study through age 40, Ypsilanti: High/Scope Press.

Tel-Aviv Educational Authority. 1999. "Evaluation of the Choice Program” (in Hebrew). 2001. "Tracking Student Mobility in Tel-Aviv" (in Hebrew).

Wondratschek, Verena , Karin Edmark and Markus Frolich. 2014. "The Short - and Long-term Effects of School Choice on Student Outcomes - Evidence from a School Choice Reform in Sweden," IZA and ZEW Discussion Paper No. 7898. 
Table 1: Descriptive Statistics and Pre and Post Treatment-Contorl Comparison of Means of Post-Secondary Schooling Outcomes , Employment Earnings, and Personal Status Outcomes (11 Years Since High School Graduation)

\begin{tabular}{|c|c|c|c|c|c|c|}
\hline & \multicolumn{3}{|c|}{ Pre: 92 and 93 cohorts } & \multicolumn{3}{|c|}{ Post: 94 cohort } \\
\hline & $\begin{array}{c}\text { Treated } \\
\text { schools } \\
\text { mean }\end{array}$ & $\begin{array}{c}\text { Non } \\
\text { treated } \\
\text { Schools } \\
\text { mean }\end{array}$ & $\begin{array}{l}\text { Mean Difference } \\
\text { (Standart error) }\end{array}$ & $\begin{array}{c}\text { Treated } \\
\text { schools } \\
\text { mean }\end{array}$ & $\begin{array}{c}\text { Non } \\
\text { treated } \\
\text { Schools } \\
\text { mean }\end{array}$ & $\begin{array}{c}\text { Mean Difference } \\
\text { (Standart error) }\end{array}$ \\
\hline & $(1)$ & $(2)$ & (3) & $(4)$ & $(5)$ & $(6)$ \\
\hline \multicolumn{7}{|l|}{ A. Enrollment } \\
\hline University & $\begin{array}{c}0.172 \\
(0.378)\end{array}$ & $\begin{array}{c}0.231 \\
(0.421)\end{array}$ & $\begin{array}{l}-0.058 \\
(0.012)\end{array}$ & $\begin{array}{c}0.158 \\
(0.365)\end{array}$ & $\begin{array}{c}0.231 \\
(0.421)\end{array}$ & $\begin{array}{l}-0.073 \\
(0.016)\end{array}$ \\
\hline Academic College & $\begin{array}{c}0.200 \\
(0.400)\end{array}$ & $\begin{array}{c}0.263 \\
(0.440)\end{array}$ & $\begin{array}{l}-0.063 \\
(0.012)\end{array}$ & $\begin{array}{c}0.254 \\
(0.436)\end{array}$ & $\begin{array}{c}0.282 \\
(0.450)\end{array}$ & $\begin{array}{l}-0.028 \\
(0.017)\end{array}$ \\
\hline \multicolumn{7}{|l|}{ B. Years of Schooling } \\
\hline University & $\begin{array}{c}0.683 \\
(1.728)\end{array}$ & $\begin{array}{c}0.974 \\
(2.044)\end{array}$ & $\begin{array}{l}-0.290 \\
(0.056)\end{array}$ & $\begin{array}{c}0.646 \\
(1.688)\end{array}$ & $\begin{array}{c}0.975 \\
(2.019)\end{array}$ & $\begin{array}{l}-0.330 \\
(0.077)\end{array}$ \\
\hline Academic College & $\begin{array}{c}0.555 \\
(1.311)\end{array}$ & $\begin{array}{c}0.822 \\
(1.595)\end{array}$ & $\begin{array}{l}-0.267 \\
(0.043)\end{array}$ & $\begin{array}{c}0.759 \\
(1.559)\end{array}$ & $\begin{array}{c}0.865 \\
(1.594)\end{array}$ & $\begin{array}{l}-0.106 \\
(0.062)\end{array}$ \\
\hline \multicolumn{7}{|l|}{ C. Labor Market Outcomes } \\
\hline Employed $(1=$ Yes, $0=$ No $)$ & $\begin{array}{c}0.868 \\
(0.338)\end{array}$ & $\begin{array}{c}0.841 \\
(0.366)\end{array}$ & $\begin{array}{c}0.028 \\
(0.010)\end{array}$ & $\begin{array}{c}0.841 \\
(0.366)\end{array}$ & $\begin{array}{c}0.844 \\
(0.363)\end{array}$ & $\begin{array}{l}-0.003 \\
(0.014)\end{array}$ \\
\hline Months Worked & $\begin{array}{c}9.284 \\
(4.369)\end{array}$ & $\begin{array}{c}9.021 \\
(4.572)\end{array}$ & $\begin{array}{c}0.264 \\
(0.126)\end{array}$ & $\begin{array}{c}9.004 \\
(4.534)\end{array}$ & $\begin{array}{c}9.081 \\
(4.524)\end{array}$ & $\begin{array}{l}-0.077 \\
(0.176)\end{array}$ \\
\hline Average Annual Earnings (NIS) & $\begin{array}{c}70,639 \\
(58,957)\end{array}$ & $\begin{array}{c}73,588 \\
(64,070)\end{array}$ & $\begin{array}{l}-2,949 \\
(1,759)\end{array}$ & $\begin{array}{c}73,091 \\
(64,950)\end{array}$ & $\begin{array}{c}75,518 \\
(67,281)\end{array}$ & $\begin{array}{l}-2,427 \\
(2,608)\end{array}$ \\
\hline \multicolumn{7}{|l|}{ D. Personal Status Outcomes } \\
\hline Married $(1=$ Yes, $0=\mathrm{No})$ & $\begin{array}{c}0.525 \\
(0.500)\end{array}$ & $\begin{array}{c}0.505 \\
(0.500)\end{array}$ & $\begin{array}{c}0.020 \\
(0.014)\end{array}$ & $\begin{array}{c}0.457 \\
(0.498)\end{array}$ & $\begin{array}{c}0.393 \\
(0.489)\end{array}$ & $\begin{array}{c}0.064 \\
(0.019)\end{array}$ \\
\hline Age of first marriage & $\begin{array}{l}25.563 \\
(3.014)\end{array}$ & $\begin{array}{l}25.871 \\
(2.901)\end{array}$ & $\begin{array}{c}-0.308 \\
(0.108)\end{array}$ & $\begin{array}{l}24.953 \\
(2.522)\end{array}$ & $\begin{array}{l}25.260 \\
(2.574)\end{array}$ & $\begin{array}{l}-0.308 \\
(0.145)\end{array}$ \\
\hline Children $(1=$ Yes, $0=$ No $)$ & $\begin{array}{c}0.447 \\
(0.497)\end{array}$ & $\begin{array}{c}0.408 \\
(0.491)\end{array}$ & $\begin{array}{c}0.039 \\
(0.014)\end{array}$ & $\begin{array}{c}0.372 \\
(0.484)\end{array}$ & $\begin{array}{c}0.281 \\
(0.449)\end{array}$ & $\begin{array}{c}0.091 \\
(0.018)\end{array}$ \\
\hline Age of first child & $\begin{array}{l}26.592 \\
(2.939)\end{array}$ & $\begin{array}{l}26.989 \\
(2.900)\end{array}$ & $\begin{array}{l}-0.397 \\
(0.122)\end{array}$ & $\begin{array}{l}25.962 \\
(2.589)\end{array}$ & $\begin{array}{l}25.962 \\
(2.649)\end{array}$ & $\begin{array}{c}0.000 \\
(0.173)\end{array}$ \\
\hline Number of children & $\begin{array}{c}0.796 \\
(1.070)\end{array}$ & $\begin{array}{c}0.692 \\
(1.025)\end{array}$ & $\begin{array}{c}0.104 \\
(0.029)\end{array}$ & $\begin{array}{c}0.612 \\
(0.976)\end{array}$ & $\begin{array}{c}0.443 \\
(0.841)\end{array}$ & $\begin{array}{c}0.169 \\
(0.034)\end{array}$ \\
\hline \multicolumn{7}{|l|}{ E. Parental Earnings } \\
\hline Average Father's Earnings in 2000-2002 & $\begin{array}{c}93,374 \\
(114,484)\end{array}$ & $\begin{array}{c}120,550 \\
(154,358)\end{array}$ & $\begin{array}{l}-27,175 \\
(4,229)\end{array}$ & $\begin{array}{c}98,227 \\
(100,779)\end{array}$ & $\begin{array}{c}122,320 \\
(158,485)\end{array}$ & $\begin{array}{l}-24,093 \\
(6,043)\end{array}$ \\
\hline Average Mother's Earnings in 2000-2002 & $\begin{array}{c}48,131 \\
(60,738)\end{array}$ & $\begin{array}{c}59,035 \\
(71,551)\end{array}$ & $\begin{array}{c}-10,904 \\
(1,952)\end{array}$ & $\begin{array}{c}53,899 \\
(84,227)\end{array}$ & $\begin{array}{c}61,873 \\
(73,365)\end{array}$ & $\begin{array}{l}-7,974 \\
(2,946)\end{array}$ \\
\hline Average Family Earnings in 2000-2002 & $\begin{array}{c}141,820 \\
(137,004)\end{array}$ & $\begin{array}{c}179,988 \\
(184,831)\end{array}$ & $\begin{array}{l}-38,168 \\
(5,080)\end{array}$ & $\begin{array}{c}153,039 \\
(139,228)\end{array}$ & $\begin{array}{c}184,665 \\
(186,745)\end{array}$ & $\begin{array}{l}-31,626 \\
(7,256)\end{array}$ \\
\hline Number of Observations & 1,519 & 8,902 & & 779 & 4,255 & \\
\hline
\end{tabular}

Notes: The table reports means and standard deviations for different post-secondary education and employment variables for 11 years after high school graduation. Each column represents these statistics for a different group as described in each column's headline. Panel A is comprised of binary variables indicating whether the individual was ever enrolled 11 years after high school graduation in a specific type of post-secondary institution. The categories are not mutually exclusive and overlapping is possible. Panel B reports the number of years of education an individual has attained by 11 years after high school graduation in each type of the post-secondary institutions listed in panel A. Panel C reports the mean of an employment indicator, annual earnings and the number of months worked 11 years after high school graduation. 
Table 2: Effect of School Choice on Post-Secondary Schooling, 12 Years Since High School Graduation

\begin{tabular}{|c|c|c|c|c|}
\hline & \multicolumn{2}{|c|}{ Enrollment } & \multicolumn{2}{|c|}{ Years of Schooling } \\
\hline & $\begin{array}{c}\text { Mean, 1992-1993 } \\
\text { Cohorts in Treated } \\
\text { Schools }\end{array}$ & Treatment & $\begin{array}{c}\text { Mean, 1992-1993 } \\
\text { Cohorts in Treated } \\
\text { Schools }\end{array}$ & Treatment \\
\hline & (1) & $(2)$ & (3) & (4) \\
\hline A. Any Post Secondary Schooling & $\begin{array}{c}0.425 \\
(0.494)\end{array}$ & $\begin{array}{c}0.046 \\
(0.022)\end{array}$ & $\begin{array}{c}1.648 \\
(2.363)\end{array}$ & $\begin{array}{c}0.187 \\
(0.089)\end{array}$ \\
\hline B. University Schooling & $\begin{array}{c}0.179 \\
(0.383)\end{array}$ & $\begin{array}{c}0.006 \\
(0.014)\end{array}$ & $\begin{array}{c}0.717 \\
(1.801)\end{array}$ & $\begin{array}{c}0.050 \\
(0.063)\end{array}$ \\
\hline C. College Schooling & $\begin{array}{c}0.209 \\
(0.407)\end{array}$ & $\begin{array}{c}0.040 \\
(0.018)\end{array}$ & $\begin{array}{c}0.589 \\
(1.361)\end{array}$ & $\begin{array}{c}0.171 \\
(0.050)\end{array}$ \\
\hline Number of Observations & 1,539 & 15,669 & 1,539 & 15,669 \\
\hline
\end{tabular}

Notes: This table presents the differences-in-differences estimates of the effect of the School Choice program on post-secondary schooling.

Columns 1-2 measure enrollment into different types of post-secondary institutions, while columns 3-4 measure completed years of post-secondary education by institution type. The results are for 12 years after high school graduation. The variable "Any Post-Secondary Education" refers to all different post-secondary institutions. Columns 1 and 3 .represent the mean and standard deviation for the 1992-1993 (untreated) cohorts in the treated schools. Columns 2 and 4 report the differences-in-differences estimates for each of the dependent variables. Standard errors are clustered at the school level. 
Table 3: Geography Discontinuity Descriptive Statistics and Pre and Post Treatment-Contorl Comparison of Means of PostSecondary Schooling Outcomes , Employment Earnings, and Personal Status Outcomes (11 Years Since High School

\begin{tabular}{|c|c|c|c|c|c|c|}
\hline & \multicolumn{2}{|c|}{ Pre: 92 and 93 cohorts } & & \multicolumn{2}{|c|}{ Post: 94 cohort } & \\
\hline & $\begin{array}{c}\text { Treated } \\
\text { schools mean }\end{array}$ & $\begin{array}{l}\text { Non treated } \\
\text { Schools mean }\end{array}$ & $\begin{array}{c}\text { Mean } \\
\text { Difference } \\
\text { (Standart } \\
\text { error) }\end{array}$ & $\begin{array}{c}\text { Treated } \\
\text { schools } \\
\text { mean }\end{array}$ & $\begin{array}{l}\text { Non treated } \\
\text { Schools } \\
\text { mean }\end{array}$ & $\begin{array}{c}\text { Mean } \\
\text { Difference } \\
\text { (Standart } \\
\text { error) }\end{array}$ \\
\hline & $(1)$ & (2) & (3) & (4) & $(5)$ & (6) \\
\hline \multicolumn{7}{|l|}{ A. Enrollment } \\
\hline University & $\begin{array}{c}0.226 \\
(0.419)\end{array}$ & $\begin{array}{c}0.297 \\
(0.457)\end{array}$ & $\begin{array}{l}-0.071 \\
(0.025)\end{array}$ & $\begin{array}{c}0.209 \\
(0.407)\end{array}$ & $\begin{array}{c}0.272 \\
(0.446)\end{array}$ & $\begin{array}{l}-0.063 \\
(0.031)\end{array}$ \\
\hline Academic College & $\begin{array}{c}0.247 \\
(0.432)\end{array}$ & $\begin{array}{c}0.293 \\
(0.455)\end{array}$ & $\begin{array}{l}-0.046 \\
(0.025)\end{array}$ & $\begin{array}{c}0.288 \\
(0.454)\end{array}$ & $\begin{array}{c}0.339 \\
(0.474)\end{array}$ & $\begin{array}{l}-0.051 \\
(0.033)\end{array}$ \\
\hline \multicolumn{7}{|l|}{ B. Years of Schooling } \\
\hline University & $\begin{array}{c}0.869 \\
(1.864)\end{array}$ & $\begin{array}{c}1.257 \\
(2.244)\end{array}$ & $\begin{array}{l}-0.387 \\
(0.117)\end{array}$ & $\begin{array}{c}0.850 \\
(1.870)\end{array}$ & $\begin{array}{c}1.162 \\
(2.146)\end{array}$ & $\begin{array}{l}-0.312 \\
(0.145)\end{array}$ \\
\hline Academic College & $\begin{array}{c}0.705 \\
(1.459)\end{array}$ & $\begin{array}{c}0.939 \\
(1.688)\end{array}$ & $\begin{array}{l}-0.234 \\
(0.089)\end{array}$ & $\begin{array}{c}0.885 \\
(1.621)\end{array}$ & $\begin{array}{c}1.084 \\
(1.748)\end{array}$ & $\begin{array}{l}-0.199 \\
(0.121)\end{array}$ \\
\hline \multicolumn{7}{|l|}{ C. Labor Market Outcomes } \\
\hline Employed $(1=$ Yes, 0 = No) & $\begin{array}{c}0.890 \\
(0.314)\end{array}$ & $\begin{array}{c}0.830 \\
(0.376)\end{array}$ & $\begin{array}{c}0.060 \\
(0.020)\end{array}$ & $\begin{array}{c}0.856 \\
(0.352)\end{array}$ & $\begin{array}{c}0.864 \\
(0.343)\end{array}$ & $\begin{array}{l}-0.008 \\
(0.025)\end{array}$ \\
\hline Average Annual Earnings (NIS) & $\begin{array}{c}77,144 \\
(59,438)\end{array}$ & $\begin{array}{c}78,738 \\
(70,772)\end{array}$ & $\begin{array}{c}-1593.381 \\
(3,688)\end{array}$ & $\begin{array}{c}80,634 \\
(71,412)\end{array}$ & $\begin{array}{c}76,893 \\
(70,312)\end{array}$ & $\begin{array}{c}3740.997 \\
(5,055)\end{array}$ \\
\hline Months worked & $\begin{array}{c}9.473 \\
(4.315)\end{array}$ & $\begin{array}{c}8.938 \\
(4.687)\end{array}$ & $\begin{array}{c}0.535 \\
(0.252)\end{array}$ & $\begin{array}{c}8.874 \\
(4.587)\end{array}$ & $\begin{array}{c}9.212 \\
(4.297)\end{array}$ & $\begin{array}{l}-0.338 \\
(0.316)\end{array}$ \\
\hline Number of Observations & 535 & 834 & & 340 & 463 & \\
\hline \multicolumn{7}{|l|}{ D. Personal Status outcomes } \\
\hline Married $(1=$ Yes, $0=$ No) & $\begin{array}{l}0.546 \\
0.499\end{array}$ & $\begin{array}{l}0.489 \\
0.501\end{array}$ & $\begin{array}{l}0.057 \\
0.039\end{array}$ & $\begin{array}{l}0.453 \\
0.499\end{array}$ & $\begin{array}{l}0.352 \\
0.478\end{array}$ & $\begin{array}{l}0.101 \\
0.035\end{array}$ \\
\hline Age of first marriage & $\begin{array}{c}25.894 \\
2.947\end{array}$ & $\begin{array}{c}26.689 \\
2.395\end{array}$ & $\begin{array}{c}-0.795 \\
0.290\end{array}$ & $\begin{array}{c}24.955 \\
2.429\end{array}$ & $\begin{array}{c}25.528 \\
2.366\end{array}$ & $\begin{array}{c}-0.573 \\
0.269\end{array}$ \\
\hline Children $(1=$ Yes, $0=$ No $)$ & $\begin{array}{c}0.403 \\
(0.491)\end{array}$ & $\begin{array}{c}0.308 \\
(0.462)\end{array}$ & $\begin{array}{c}0.095 \\
(0.037)\end{array}$ & $\begin{array}{c}0.335 \\
(0.473)\end{array}$ & $\begin{array}{c}0.222 \\
(0.416)\end{array}$ & $\begin{array}{c}0.113 \\
(0.032)\end{array}$ \\
\hline Age of first child & $\begin{array}{c}26.917 \\
2.889\end{array}$ & $\begin{array}{c}27.959 \\
2.375\end{array}$ & $\begin{array}{c}-1.042 \\
0.340\end{array}$ & $\begin{array}{c}24.955 \\
2.429\end{array}$ & $\begin{array}{c}25.528 \\
2.366\end{array}$ & $\begin{array}{l}-0.573 \\
0.269\end{array}$ \\
\hline Number of children & $\begin{array}{c}(0.713) \\
1.063\end{array}$ & $\begin{array}{c}(0.486) \\
0.794\end{array}$ & $\begin{array}{c}(0.227) \\
0.072\end{array}$ & $\begin{array}{c}(0.535) \\
0.926\end{array}$ & $\begin{array}{c}(0.333) \\
0.710\end{array}$ & $\begin{array}{c}(0.203) \\
0.058\end{array}$ \\
\hline \multicolumn{7}{|l|}{ E. Parental Earnings } \\
\hline Average Father's Earnings in 2000-2002 & $\begin{array}{c}112,853 \\
(140,079)\end{array}$ & $\begin{array}{c}139,061 \\
(153,169)\end{array}$ & $\begin{array}{l}-26,208 \\
(8,343)\end{array}$ & $\begin{array}{c}107,873 \\
(112,571)\end{array}$ & $\begin{array}{c}138,760 \\
(151,137)\end{array}$ & $\begin{array}{l}-30,887 \\
(9,971)\end{array}$ \\
\hline Average Mother's Earnings in 2000-2002 & $\begin{array}{c}56,552 \\
(70,152)\end{array}$ & $\begin{array}{c}71,761 \\
(76,009)\end{array}$ & $\begin{array}{l}-15,210 \\
(4,093)\end{array}$ & $\begin{array}{c}61,268 \\
(110,611)\end{array}$ & $\begin{array}{c}76,347 \\
(93,145)\end{array}$ & $\begin{array}{l}-15,079 \\
(7,237)\end{array}$ \\
\hline Average Family Earnings in $2000-2002$ & $\begin{array}{c}169,279 \\
(162,594)\end{array}$ & $\begin{array}{c}211,501 \\
(181,331)\end{array}$ & $\begin{array}{l}-42,222 \\
(9,827)\end{array}$ & $\begin{array}{c}169,992 \\
(163,890)\end{array}$ & $\begin{array}{c}215,898 \\
(198,632)\end{array}$ & $\begin{array}{l}-45,906 \\
(13,600)\end{array}$ \\
\hline Number of Observations & 1,519 & 8,902 & & 779 & 4,255 & \\
\hline
\end{tabular}

Notes: The table reports means and standard deviations for different post-secondary education and employment variables for 11 years after high school graduation for the geography discontinuity sample described in the paper. Each column represents these statistics for a different group as described in each column's headline. Panel A is comprised of binary variables indicating whether the individual was ever enrolled until 11 years after high school graduation in a specific type of post-secondary institution. The categories are not mutually exclusive and overlapping is possible. Panel B reports the number of years of education an individual has attained 11 years after high school graduation in each type of the post-secondary institutions listed in panel A. Panel C reports the mean of an employment indicator, annual earnings and the number of months worked 11 years after high school graduation. 
Table 4: Geography Discontinuity Estimates of the Effect of School Choice on Post-Secondary Schooling, 10-12 Years Since High School Graduation

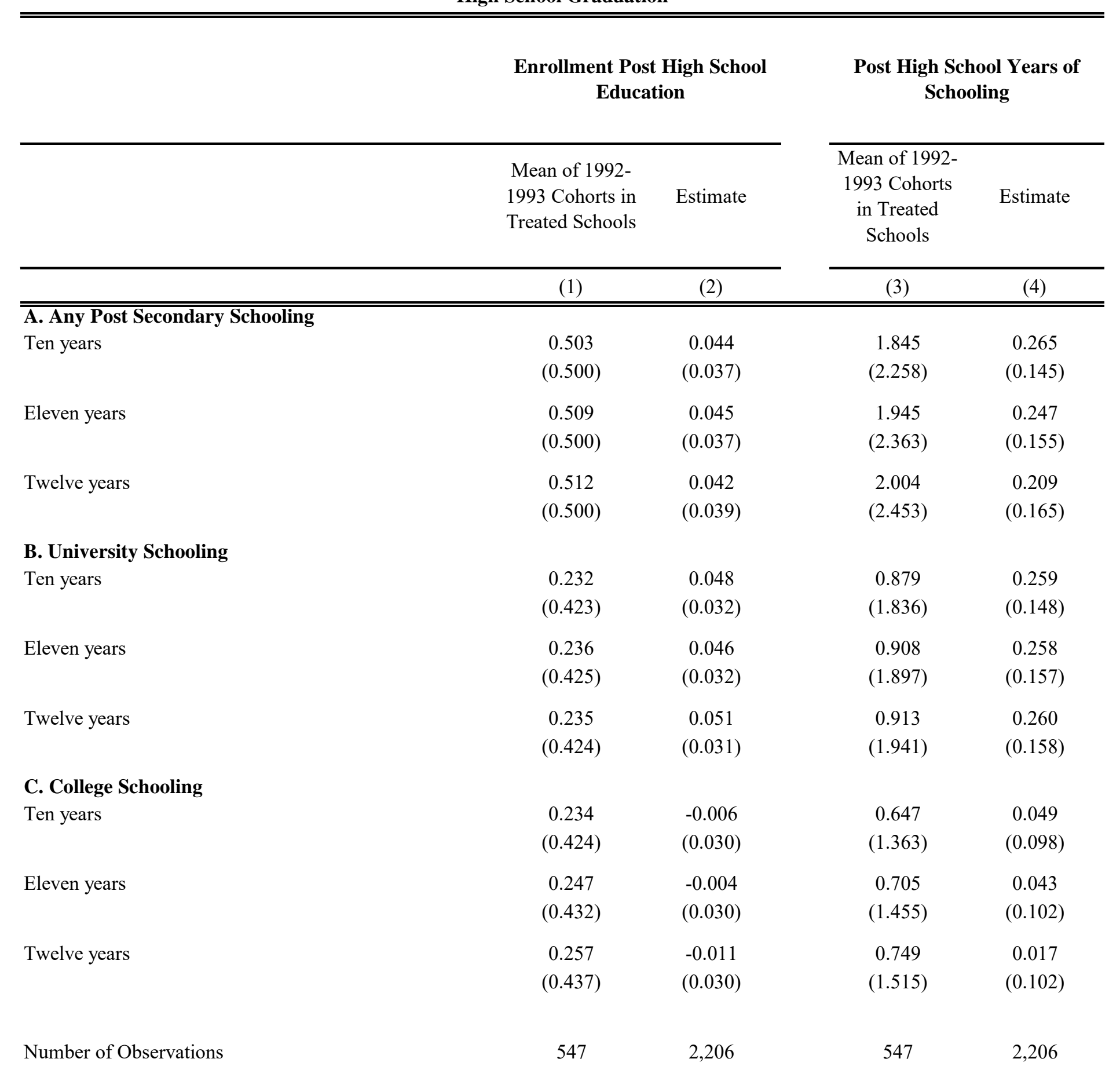

Notes: This table presents the differences-in-differences estimates of the effect of the School Choice program on post-secondary schooling for the geography discontinuity sample described in the paper. Columns 1-2 measure enrollment into different types of post-secondary institutions, while columns 3-4 measure completed years of post-secondary education by institution type. The results are for 10-12 years after high sche gadution. The varible "Any Post-Scosto are for 10-12 yeas atsecondary institutions. Colum 1 and 3 represent the man and standard deviation for the 1992-1993 (untreated) cohorts in the treated schools. Columns 2 and 4 the school level. 
Table 5: Effect of School Choice on Employment and Income By Years Since High School Graduation

\begin{tabular}{|c|c|c|c|c|c|c|c|c|}
\hline & \multicolumn{2}{|c|}{11 Years } & \multicolumn{2}{|c|}{12 Years } & \multicolumn{2}{|c|}{13 Years } & \multicolumn{2}{|c|}{$\begin{array}{c}\text { Stacked Regression 11-13 } \\
\text { Years } \\
\end{array}$} \\
\hline & $\begin{array}{l}\text { mean, 1992- } \\
1993 \text { Cohorts in } \\
\text { Treated Schools }\end{array}$ & Estimate & $\begin{array}{l}\text { mean, 1992- } \\
1993 \text { Cohorts in } \\
\text { Treated Schools }\end{array}$ & Estimate & $\begin{array}{l}\text { mean, 1992- } \\
1993 \text { Cohorts in } \\
\text { Treated Schools }\end{array}$ & Estimate & $\begin{array}{c}\text { 1992-1993 } \\
\text { Cohorts in } \\
\text { Treated Schools }\end{array}$ & Estimate \\
\hline & (1) & (2) & (3) & (4) & $(5)$ & (6) & (7) & (8) \\
\hline Employment Indicator $(1=$ Yes, $0=\mathrm{No})$ & $\begin{array}{c}0.870 \\
(0.337)\end{array}$ & $\begin{array}{l}-0.031 \\
(0.015)\end{array}$ & $\begin{array}{c}0.852 \\
(0.355)\end{array}$ & $\begin{array}{l}-0.012 \\
(0.014)\end{array}$ & $\begin{array}{c}0.854 \\
(0.353)\end{array}$ & $\begin{array}{l}-0.009 \\
(0.012)\end{array}$ & $\begin{array}{c}0.858 \\
(0.349)\end{array}$ & $\begin{array}{l}-0.015 \\
(0.011)\end{array}$ \\
\hline Total Annual Earnings (2009 NIS) & $\begin{array}{c}74,709 \\
(64,595)\end{array}$ & $\begin{array}{c}3,368 \\
(2,285)\end{array}$ & $\begin{array}{c}78,313 \\
(67,521)\end{array}$ & $\begin{array}{c}5,544 \\
(2,500)\end{array}$ & $\begin{array}{c}81,230 \\
(70,432)\end{array}$ & $\begin{array}{c}5,662 \\
(2,668)\end{array}$ & $\begin{array}{c}78,188 \\
(67,808)\end{array}$ & $\begin{array}{c}4,763 \\
(2,282)\end{array}$ \\
\hline Months worked & $\begin{array}{c}9.310 \\
(4.354)\end{array}$ & $\begin{array}{l}-0.317 \\
(0.198)\end{array}$ & $\begin{array}{c}9.251 \\
(4.453)\end{array}$ & $\begin{array}{l}-0.313 \\
(0.155)\end{array}$ & $\begin{array}{c}9.170 \\
(4.456)\end{array}$ & $\begin{array}{l}-0.154 \\
(0.150)\end{array}$ & $\begin{array}{c}9.228 \\
(4.433)\end{array}$ & $\begin{array}{l}-0.241 \\
(0.146)\end{array}$ \\
\hline Number of Observations & 1,537 & 15,634 & 1,532 & 15,616 & 1,527 & 15,578 & 4,668 & 47,276 \\
\hline
\end{tabular}

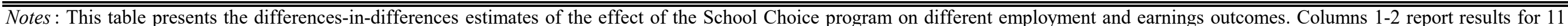

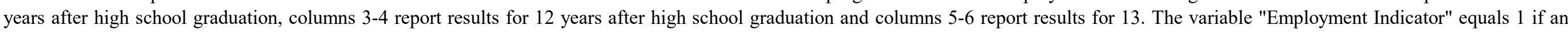

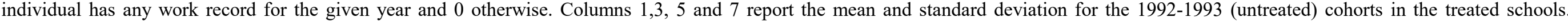

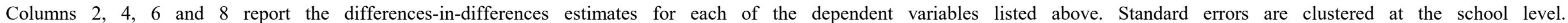


Table 6: Goegraphy Discontinuity Estimates of the Effect of School Choice on Employment and Income By Years Since High School Graduation

\begin{tabular}{|c|c|c|c|c|c|c|c|c|}
\hline & \multicolumn{2}{|c|}{11 Years } & \multicolumn{2}{|c|}{12 Years } & \multicolumn{2}{|c|}{13 Years } & \multicolumn{2}{|c|}{ Stacked Regression 11-13 years } \\
\hline & $\begin{array}{l}\text { Mean of 1992- } \\
1993 \text { Cohorts in } \\
\text { Treated Schools } \\
\end{array}$ & Estimate & $\begin{array}{l}\text { Mean of 1992- } \\
1993 \text { Cohorts in } \\
\text { Treated Schools } \\
\end{array}$ & Estimate & $\begin{array}{c}\text { Mean 1992-1993 } \\
\text { Cohorts in Treated } \\
\text { Schools } \\
\end{array}$ & Estimate & $\begin{array}{c}\text { Mean 1992-1993 } \\
\text { Cohorts in Treated } \\
\text { Schools } \\
\end{array}$ & Estimate \\
\hline & $(1)$ & $(2)$ & (4) & $(5)$ & $(7)$ & $(8)$ & $(7)$ & $(8)$ \\
\hline Employment Indicator $(1=$ Yes, $0=$ No $)$ & $\begin{array}{c}0.892 \\
(0.311)\end{array}$ & $\begin{array}{l}-0.065 \\
(0.027)\end{array}$ & $\begin{array}{c}0.867 \\
(0.340)\end{array}$ & $\begin{array}{l}-0.066 \\
(0.026)\end{array}$ & $\begin{array}{c}0.865 \\
(0.343)\end{array}$ & $\begin{array}{l}-0.042 \\
(0.023)\end{array}$ & $\begin{array}{c}0.872 \\
(0.335)\end{array}$ & $\begin{array}{l}-0.058 \\
(0.023)\end{array}$ \\
\hline Total Annual Earnings (2009 NIS) & $\begin{array}{c}83,397 \\
(67,627)\end{array}$ & $\begin{array}{l}10,099 \\
(4,341)\end{array}$ & $\begin{array}{c}87,782 \\
(71,565)\end{array}$ & $\begin{array}{c}9,044 \\
(5,281)\end{array}$ & $\begin{array}{c}92,623 \\
(76,376)\end{array}$ & $\begin{array}{c}6,005 \\
(5,882)\end{array}$ & $\begin{array}{c}87,810 \\
(72,250)\end{array}$ & $\begin{array}{c}7,613 \\
(4,859)\end{array}$ \\
\hline Months worked & $\begin{array}{c}9.720 \\
(4.061)\end{array}$ & $\begin{array}{l}-0.678 \\
(0.347)\end{array}$ & $\begin{array}{c}9.497 \\
(4.298)\end{array}$ & $\begin{array}{l}-0.752 \\
(0.273)\end{array}$ & $\begin{array}{c}9.538 \\
(4.286)\end{array}$ & $\begin{array}{l}-0.758 \\
(0.256)\end{array}$ & $\begin{array}{c}9.534 \\
(4.256)\end{array}$ & $\begin{array}{l}-0.747 \\
(0.262)\end{array}$ \\
\hline Number of Observations & 546 & 2,204 & 546 & 2,204 & 539 & 2,184 & 1,668 & 6,659 \\
\hline
\end{tabular}


Table 7: Effect of the School Choice when High School Educational Outcomes are Added As Contorls in the DID Regression

\begin{tabular}{|c|c|c|c|c|c|c|}
\hline & \multicolumn{6}{|c|}{ Added Control Variables } \\
\hline & $\begin{array}{c}\text { Original } \\
\text { Estimate/ No } \\
\text { Added } \\
\text { Variables } \\
\end{array}$ & $\begin{array}{c}\text { Average } \\
\text { Matriculation } \\
\text { Score }\end{array}$ & $\begin{array}{l}\text { Received High } \\
\text { School } \\
\text { Matriculation }\end{array}$ & $\begin{array}{c}\text { Number of Credit } \\
\text { Units in } \\
\text { Matriculation } \\
\text { Exams } \\
\end{array}$ & $\begin{array}{c}\text { Number of } \\
\text { Science Credit } \\
\text { Units }\end{array}$ & $\begin{array}{l}\text { All High School } \\
\text { Outcome }\end{array}$ \\
\hline & $(1)$ & $(2)$ & (3) & $(4)$ & $(5)$ & $(6)$ \\
\hline \multicolumn{7}{|l|}{ Full Sample } \\
\hline Enrollment in college 12 years after high school garduation $(1=$ Yes, $0=$ No $)$ & $\begin{array}{c}0.040 \\
(0.018)\end{array}$ & $\begin{array}{c}0.017 \\
(0.017)\end{array}$ & $\begin{array}{c}0.019 \\
(0.018)\end{array}$ & $\begin{array}{c}0.015 \\
(0.017)\end{array}$ & $\begin{array}{c}0.036 \\
(0.018)\end{array}$ & $\begin{array}{c}0.013 \\
(0.017)\end{array}$ \\
\hline Completed Years of college Schooling 12 years after high school garduate & $\begin{array}{c}0.171 \\
(0.050)\end{array}$ & $\begin{array}{c}0.094 \\
(0.046)\end{array}$ & $\begin{array}{c}0.096 \\
(0.049)\end{array}$ & $\begin{array}{c}0.087 \\
(0.047)\end{array}$ & $\begin{array}{c}0.153 \\
(0.051)\end{array}$ & $\begin{array}{c}0.079 \\
(0.048)\end{array}$ \\
\hline Annual Earnings 11-13 years after high school graduate (2009 NIS) & $\begin{array}{c}4,763 \\
(2,282)\end{array}$ & $\begin{array}{c}653 \\
(2,423)\end{array}$ & $\begin{array}{c}1,700 \\
(2,301)\end{array}$ & $\begin{array}{c}640 \\
(2,394)\end{array}$ & $\begin{array}{c}2,585 \\
(2,182)\end{array}$ & $\begin{array}{c}79 \\
(2,288)\end{array}$ \\
\hline \multicolumn{7}{|l|}{ Geography Discontinuity Sample (500m sample) } \\
\hline Enrollment in college 12 years after high school garduation $(1=$ Yes, $0=$ No $)$ & $\begin{array}{c}-0.011 \\
(0.030)\end{array}$ & $\begin{array}{c}-0.044 \\
(0.030)\end{array}$ & $\begin{array}{l}-0.039 \\
(0.031)\end{array}$ & $\begin{array}{c}-0.043 \\
(0.029)\end{array}$ & $\begin{array}{c}-0.012 \\
(0.030)\end{array}$ & $\begin{array}{l}-0.045 \\
(0.029)\end{array}$ \\
\hline Completed Years of college Schooling 12 years after high school garduation & $\begin{array}{c}0.017 \\
(0.102)\end{array}$ & $\begin{array}{c}-0.096 \\
(0.105)\end{array}$ & $\begin{array}{c}-0.083 \\
(0.110)\end{array}$ & $\begin{array}{c}-0.093 \\
(0.105)\end{array}$ & $\begin{array}{c}0.009 \\
(0.103)\end{array}$ & $\begin{array}{c}-0.102 \\
(0.110)\end{array}$ \\
\hline Annual Earnings 11-13 years after high school graduate (2009 NIS) & $\begin{array}{c}7,613 \\
(4,859)\end{array}$ & $\begin{array}{c}1,337 \\
(4,678)\end{array}$ & $\begin{array}{c}3,425 \\
(4,660)\end{array}$ & $\begin{array}{c}2,042 \\
(4,629)\end{array}$ & $\begin{array}{c}4,506 \\
(4,675)\end{array}$ & $\begin{array}{c}811 \\
(4,552)\end{array}$ \\
\hline
\end{tabular}

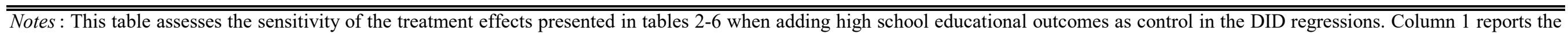

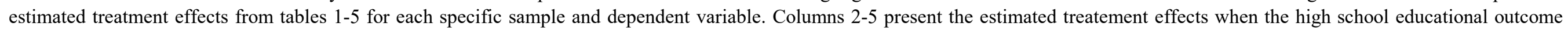

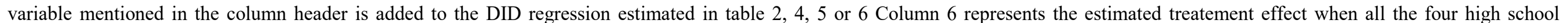
educational outcomes are added together to the DID regressions. Standard errors are clustered at the school level. 
Table 8: Effect of School Choice on High School Outcomes By Gender

\begin{tabular}{|c|c|c|c|c|}
\hline & \multicolumn{2}{|c|}{ Boys } & \multicolumn{2}{|c|}{ Girls } \\
\hline & $\begin{array}{c}\text { Mean, 1992- } \\
1993 \text { Cohorts } \\
\text { in Treated } \\
\text { Schools } \\
\end{array}$ & Treatment & $\begin{array}{c}\text { Mean, 1992- } \\
1993 \text { Cohorts } \\
\text { in Treated } \\
\text { Schools } \\
\end{array}$ & Treatment \\
\hline & $(1)$ & $(2)$ & $(5)$ & $(6)$ \\
\hline Drop out & $\begin{array}{c}0.266 \\
(0.442)\end{array}$ & $\begin{array}{c}-0.101 \\
(0.027)\end{array}$ & $\begin{array}{c}0.103 \\
(0.304)\end{array}$ & $\begin{array}{c}-0.021 \\
(0.014)\end{array}$ \\
\hline Eligible for Bagrut & $\begin{array}{c}0.377 \\
(0.485)\end{array}$ & $\begin{array}{c}0.071 \\
(0.024)\end{array}$ & $\begin{array}{c}0.513 \\
(0.500)\end{array}$ & $\begin{array}{c}0.090 \\
(0.029)\end{array}$ \\
\hline Average score & $\begin{array}{c}53.499 \\
(37.166)\end{array}$ & $\begin{array}{c}8.856 \\
(1.784)\end{array}$ & $\begin{array}{c}66.823 \\
(32.578)\end{array}$ & $\begin{array}{c}3.968 \\
(1.643)\end{array}$ \\
\hline Number of science credits & $\begin{array}{c}1.414 \\
(3.101)\end{array}$ & $\begin{array}{c}0.466 \\
(0.199)\end{array}$ & $\begin{array}{c}1.709 \\
(3.606)\end{array}$ & $\begin{array}{c}0.333 \\
(0.201)\end{array}$ \\
\hline Number of Credit Units in Matriculation Exams & $\begin{array}{c}14.427 \\
(11.641)\end{array}$ & $\begin{array}{c}2.913 \\
(0.590)\end{array}$ & $\begin{array}{c}17.312 \\
(10.000)\end{array}$ & $\begin{array}{c}1.167 \\
(0.541)\end{array}$ \\
\hline Number of honor-level subjects & $\begin{array}{c}1.390 \\
(1.540)\end{array}$ & $\begin{array}{c}0.386 \\
(0.085)\end{array}$ & $\begin{array}{c}1.698 \\
(1.346)\end{array}$ & $\begin{array}{c}0.182 \\
(0.068)\end{array}$ \\
\hline Number of Observations & 801 & 8,093 & 741 & 7,601 \\
\hline
\end{tabular}

Notes: This table presents the differences-in-differences estimates of the effect of the School Choice program on high school outcomes for boys and girls separately. Columns 1 and 3 represent the mean and standard deviation for the 1992-1993 (untreated) cohorts in the treated schools. Columns 2 and 4 report the differences-in-differences estimates for each of the dependent variables. Standard errors are clustered at the school level. 
Table 9: Effect of School Choice on Post-Secondary Schooling, 12 Years Since High School Graduation

\begin{tabular}{|c|c|c|c|c|c|c|c|c|}
\hline & \multicolumn{4}{|c|}{ Boys } & \multicolumn{4}{|c|}{ Girls } \\
\hline & \multicolumn{2}{|c|}{ Enrollment } & \multicolumn{2}{|c|}{ Years of Schooling } & \multicolumn{2}{|c|}{ Enrollment } & \multicolumn{2}{|c|}{ Years of Schooling } \\
\hline & $\begin{array}{c}\text { Mean, 1992- } \\
1993 \text { Cohorts } \\
\text { in Treated } \\
\text { Schools } \\
\end{array}$ & Treatment & $\begin{array}{c}\text { Mean, 1992- } \\
1993 \text { Cohorts } \\
\text { in Treated } \\
\text { Schools } \\
\end{array}$ & Treatment & $\begin{array}{c}\text { Mean, 1992- } \\
1993 \text { Cohorts } \\
\text { in Treated } \\
\text { Schools } \\
\end{array}$ & Treatment & $\begin{array}{l}\text { Mean, 1992- } \\
1993 \text { Cohorts in } \\
\text { Treated Schools }\end{array}$ & Treatment \\
\hline & $(1)$ & $(2)$ & $(3)$ & $(4)$ & $(5)$ & $(6)$ & $(7)$ & $(8)$ \\
\hline A. Any Post Secondary Schooling & $\begin{array}{c}0.372 \\
(0.484)\end{array}$ & $\begin{array}{c}0.093 \\
(0.031)\end{array}$ & $\begin{array}{c}1.447 \\
(2.323)\end{array}$ & $\begin{array}{c}0.331 \\
(0.120)\end{array}$ & $\begin{array}{c}0.481 \\
(0.500)\end{array}$ & $\begin{array}{l}-0.003 \\
(0.029)\end{array}$ & $\begin{array}{c}1.864 \\
(2.389)\end{array}$ & $\begin{array}{c}0.029 \\
(0.136)\end{array}$ \\
\hline B. University Schooling & $\begin{array}{c}0.143 \\
(0.350)\end{array}$ & $\begin{array}{c}0.030 \\
(0.023)\end{array}$ & $\begin{array}{c}0.605 \\
(1.751)\end{array}$ & $\begin{array}{c}0.113 \\
(0.105)\end{array}$ & $\begin{array}{c}0.218 \\
(0.413)\end{array}$ & $\begin{array}{l}-0.021 \\
(0.022)\end{array}$ & $\begin{array}{c}0.838 \\
(1.848)\end{array}$ & $\begin{array}{l}-0.015 \\
(0.108)\end{array}$ \\
\hline C. College Schooling & $\begin{array}{c}0.191 \\
(0.393)\end{array}$ & $\begin{array}{c}0.039 \\
(0.024)\end{array}$ & $\begin{array}{c}0.561 \\
(1.340)\end{array}$ & $\begin{array}{c}0.197 \\
(0.076)\end{array}$ & $\begin{array}{c}0.222 \\
(0.416)\end{array}$ & $\begin{array}{c}0.039 \\
(0.022)\end{array}$ & $\begin{array}{c}0.619 \\
(1.383)\end{array}$ & $\begin{array}{c}0.133 \\
(0.066)\end{array}$ \\
\hline Number of Observations & 798 & 8,064 & 798 & 8,064 & 741 & 7,605 & 741 & 7,605 \\
\hline
\end{tabular}

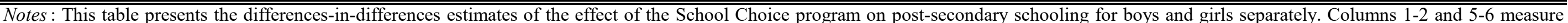

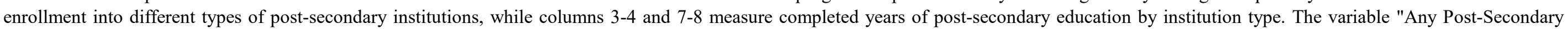

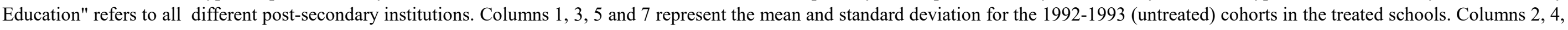

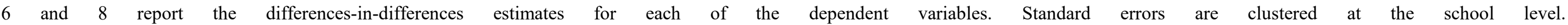


Table 10: Effect of School Choice on Employment and Income, By Gender and Years Since High School Graduation

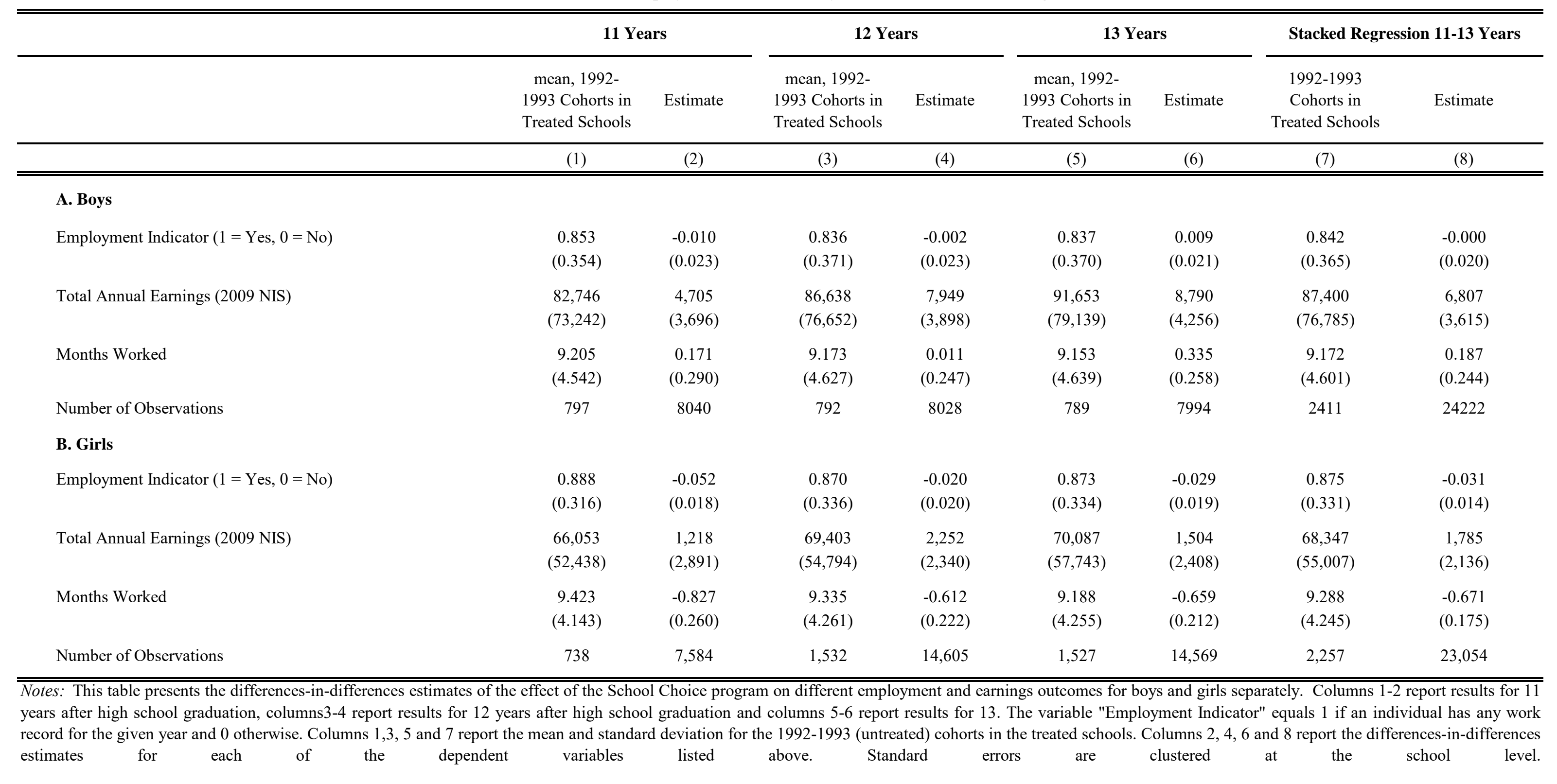


Table 11: Effect of School Choice on Marriage and Fertility, 10 Years After High School

\begin{tabular}{|c|c|c|c|c|c|c|}
\hline & \multicolumn{2}{|c|}{ Entire Sample } & \multicolumn{2}{|c|}{ Boys } & \multicolumn{2}{|c|}{ Girls } \\
\hline & $\begin{array}{c}\text { mean, 1992-1993 } \\
\text { Cohorts in Treated } \\
\text { Schools }\end{array}$ & Estimate & $\begin{array}{c}\text { mean, 1992-1993 } \\
\text { Cohorts in Treated } \\
\text { Schools }\end{array}$ & Estimate & $\begin{array}{c}\text { mean, 1992-1993 } \\
\text { Cohorts in Treated } \\
\text { Schools }\end{array}$ & Estimate \\
\hline & (1) & (2) & (3) & (4) & (5) & (6) \\
\hline Children $(1=$ Yes, $0=$ No $)$ & $\begin{array}{c}0.433 \\
(0.496)\end{array}$ & $\begin{array}{c}0.031 \\
(0.021)\end{array}$ & $\begin{array}{c}0.355 \\
(0.479)\end{array}$ & $\begin{array}{l}-0.021 \\
(0.026)\end{array}$ & $\begin{array}{c}0.518 \\
(0.500)\end{array}$ & $\begin{array}{c}0.088 \\
(0.030)\end{array}$ \\
\hline Number of children & $\begin{array}{c}0.794 \\
(1.069)\end{array}$ & $\begin{array}{c}0.021 \\
(0.045)\end{array}$ & $\begin{array}{c}0.614 \\
(0.966)\end{array}$ & $\begin{array}{l}-0.102 \\
(0.051)\end{array}$ & $\begin{array}{c}0.972 \\
(1.136)\end{array}$ & $\begin{array}{c}0.158 \\
(0.065)\end{array}$ \\
\hline Age of first child & $\begin{array}{l}26.590 \\
(2.941)\end{array}$ & $\begin{array}{c}0.513 \\
(0.174)\end{array}$ & $\begin{array}{l}27.316 \\
(2.530)\end{array}$ & $\begin{array}{c}0.460 \\
(0.255)\end{array}$ & $\begin{array}{l}26.067 \\
(3.103)\end{array}$ & $\begin{array}{c}0.522 \\
(0.241)\end{array}$ \\
\hline Married $(1=$ Yes, $0=$ No $)$ & $\begin{array}{c}0.562 \\
(0.496)\end{array}$ & $\begin{array}{c}0.028 \\
(0.021)\end{array}$ & $\begin{array}{c}0.499 \\
(0.500)\end{array}$ & $\begin{array}{l}-0.022 \\
(0.030)\end{array}$ & $\begin{array}{c}0.629 \\
(0.483)\end{array}$ & $\begin{array}{c}0.081 \\
(0.025)\end{array}$ \\
\hline Age of first marriage & $\begin{array}{l}25.567 \\
(3.014)\end{array}$ & $\begin{array}{c}0.125 \\
(0.151)\end{array}$ & $\begin{array}{l}26.561 \\
(2.537)\end{array}$ & $\begin{array}{c}0.345 \\
(0.172)\end{array}$ & $\begin{array}{l}24.752 \\
(3.134)\end{array}$ & $\begin{array}{c}0.004 \\
(0.232)\end{array}$ \\
\hline Number of Observations & 1,542 & 15,708 & 801 & 8,098 & 741 & 7,610 \\
\hline
\end{tabular}

Notes: This table presents the differences-in-differences estimates of the effect of the School Choice program on different personal outcomes. Columns 1-2 report results for the entire sample while columns 3-4 and columns 5-6 report the results for boys and girls respectivly.Columns 1,3, and 5 report the mean and standard deviation for the 1992-1993 (untreated) cohorts in the treated schools. Columns 2,4, and 6 report the differences-in-differences estimates for each of the dependent variables listed above. Standard errors are clustered at the school level. 
Mean and Treatment Effect: Academic College Enrollment

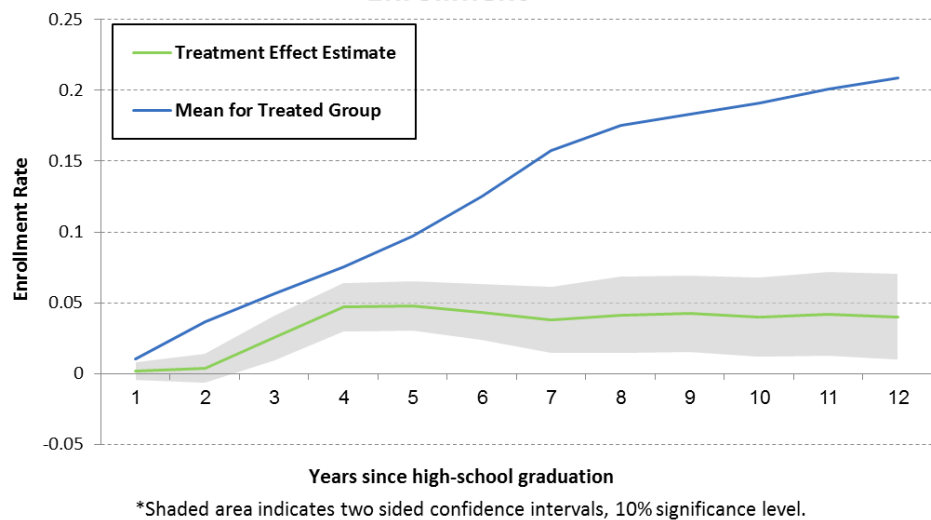

Figure 2

Mean and Treatment Effect: University Enrollment

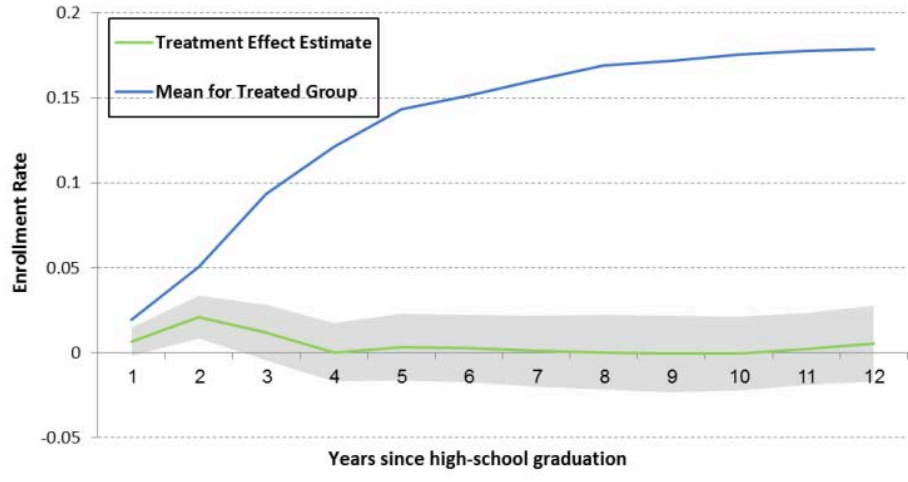

*Shaded area indicates two sided confidence intervals, $10 \%$ significance level.

\section{Figure 3}

Mean and Treatment Effect: Post-Secondary Enrollment

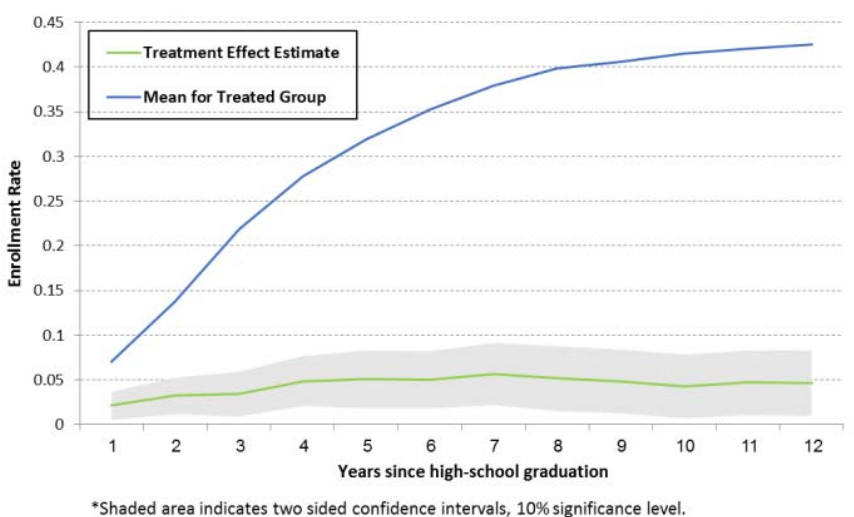

*Shaded area indicates two sided confidence intervals, 10\% significance level,
Mean and Treatment Effect: Completed Years of Academic College Schooling

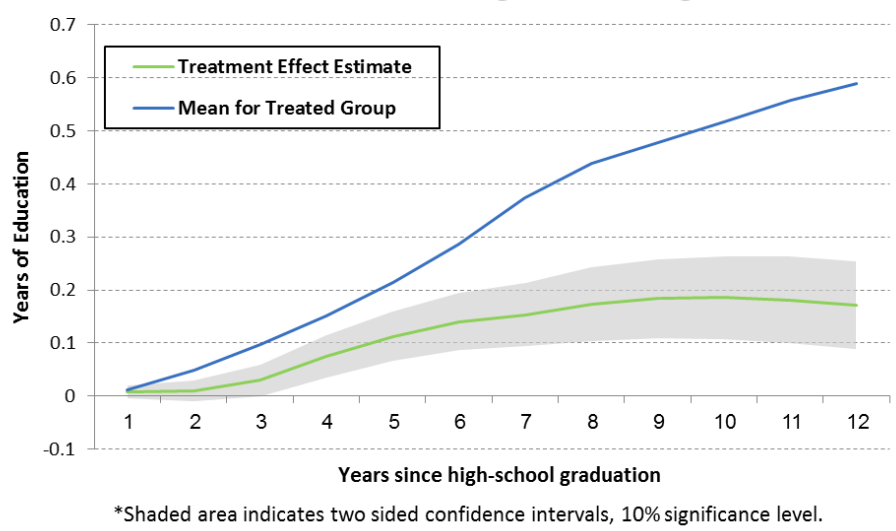

Figure 2A

Mean and Treatment Effect: Completed Years of University Schooling

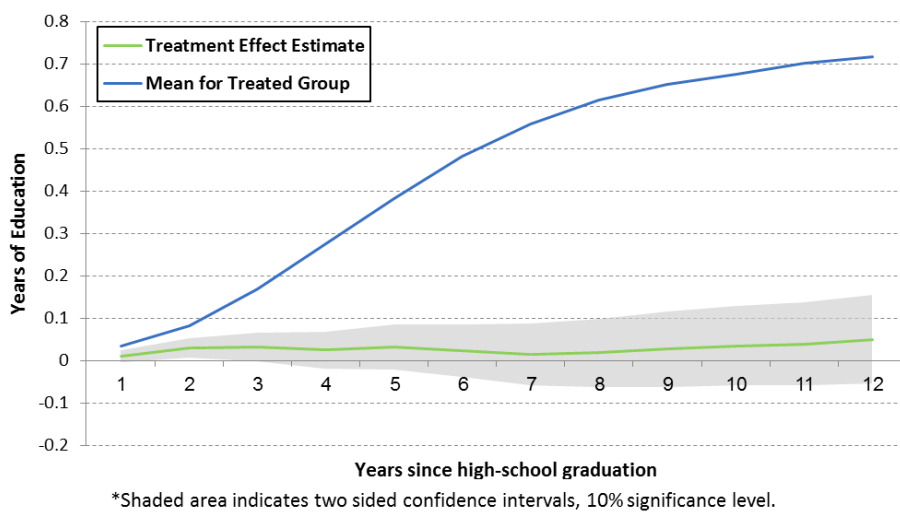

Figure 3A

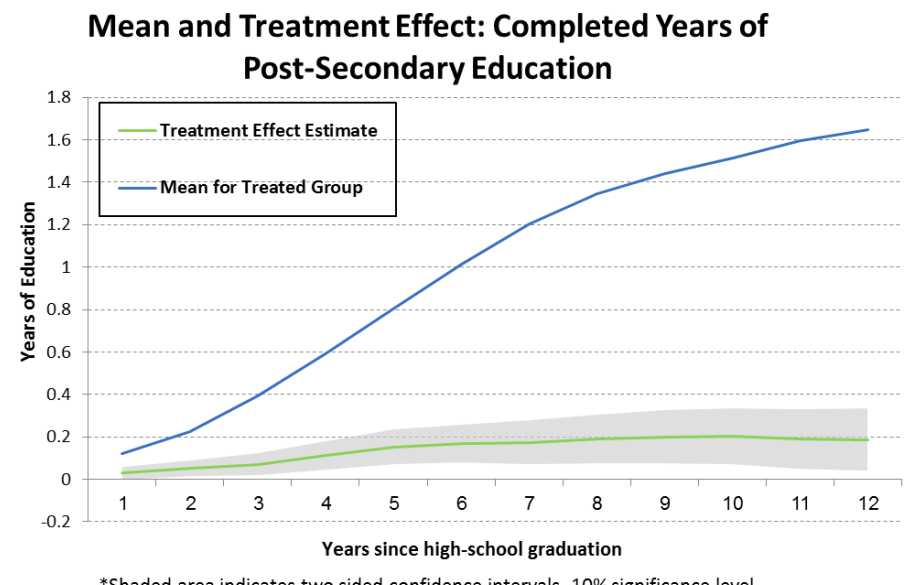




\section{Figure 4}

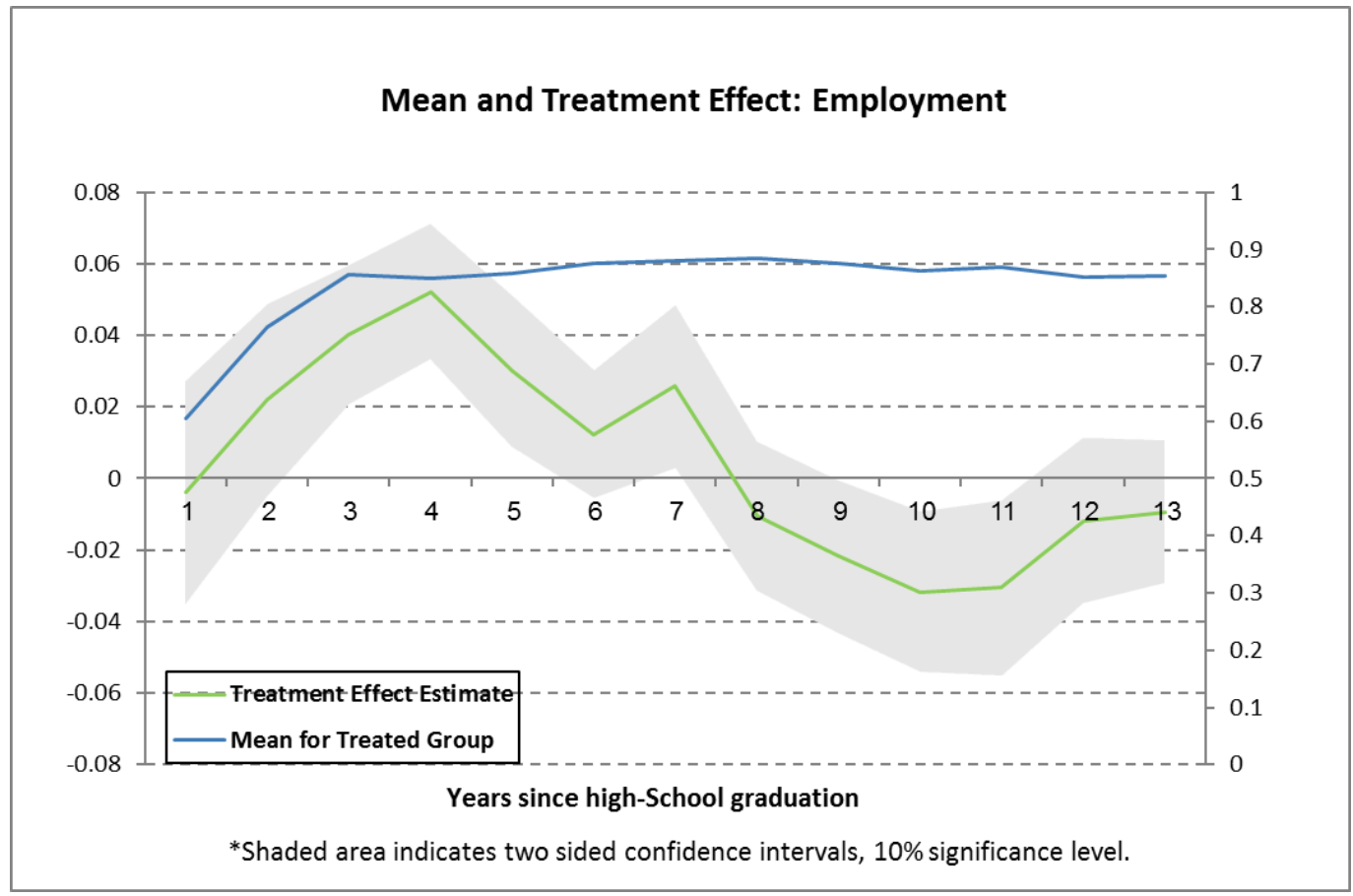

Figure 5

Mean and Treatment Effect: Annual Earnings - 2009 Prices NI Shekels

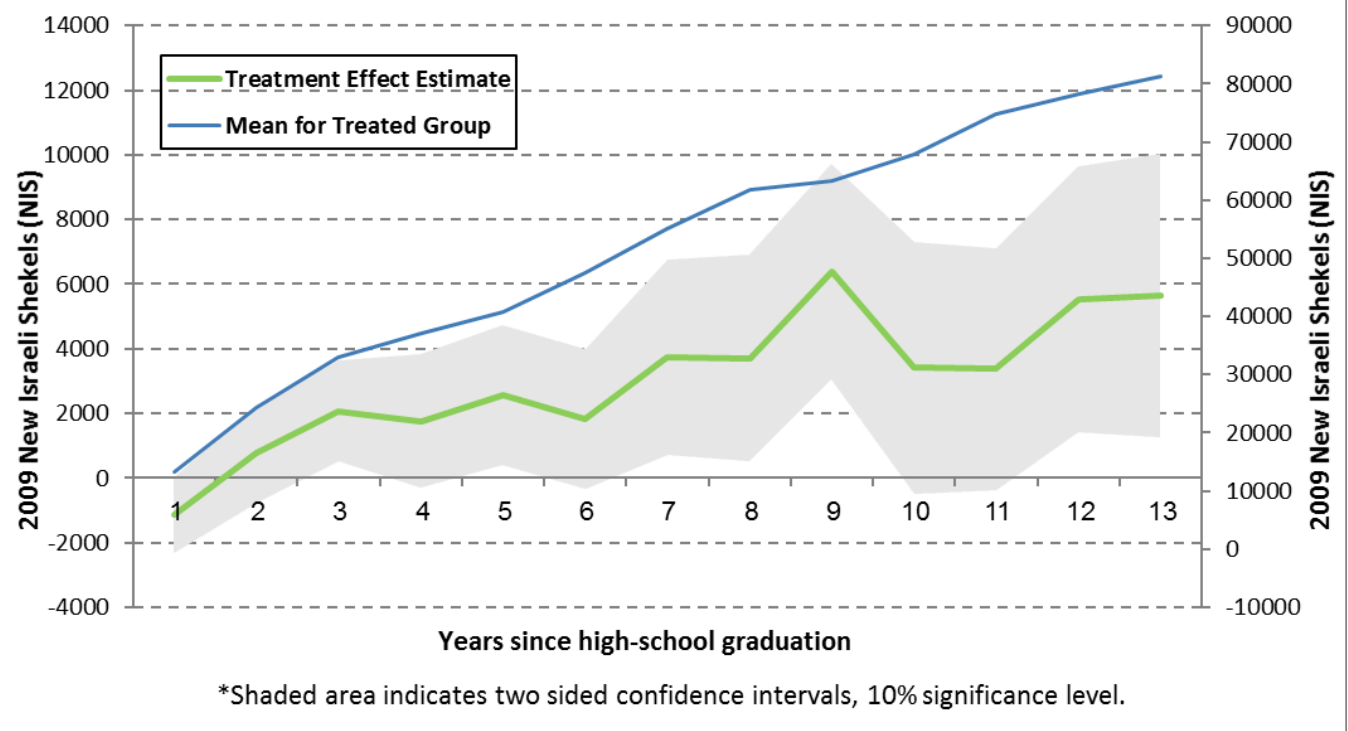

